Review

\title{
Copper accumulation in vineyard soils: Rhizosphere processes and agronomic practices to limit its toxicity
}

\author{
Gustavo Brunetto ${ }^{\mathrm{a}}$, George Wellington Bastos de Melo ${ }^{\mathrm{b}}$, Roberto Terzano ${ }^{\mathrm{c}}$, \\ Daniele Del Buono ${ }^{\mathrm{d}}$, Stefania Astolfi ${ }^{\mathrm{e}}$, Nicola Tomasi ${ }^{\mathrm{f}}$, Youry Pii ${ }^{\mathrm{g}}$, Tanja Mimmo ${ }^{\mathrm{g}, *}$, \\ Stefano Cesco ${ }^{\mathrm{g}}$ \\ ${ }^{a}$ Departament of Soil Science, Federal University of Santa Maria, 97105-900, Santa Maria, Rio Grande do Sul, Brazil \\ ${ }^{\mathrm{b}}$ National Research Center of Grape and Wine (Centro Nacional de Pesquisa de Uva e Vinho - CNPUV), Brazilian Agricultural Research Corporation \\ (Empresa Brasileira de Pesquisa Agropecuária - Embrapa), Bento Gonçalves, Rio Grande do Sul, CEP: 95700-000, Brazil \\ ' Dipartimento di Scienze del Suolo, della Pianta e degli Alimenti, University of Bari “Aldo Moro", I-70126, Bari, Italy \\ ${ }^{\mathrm{d}}$ Dipartimento di Scienze Agrarie, Alimentari e Ambientali, Università degli Studi di Perugia, Borgo XX Giugno 74, 06121 Perugia, Italy \\ e Department of Agricultural and Forestry Sciences (DAFNE), Università della Tuscia, Viterbo, I-01100, Italy \\ ${ }^{\mathrm{f}}$ Dipartimento di Scienze Agrarie e Ambientali, University of Udine, I-33100, Udine, Italy \\ ${ }^{\mathrm{g}}$ Faculty of Science and Technology, Free University of Bolzano, Piazza Università 5, 39100, Bolzano, Italy
}

\section{H I G H L I G H T S}

- Speciation of $\mathrm{Cu}$ in soil solution is crucial to determine its toxicity to organisms.

- Root exudation is involved in both $\mathrm{Cu}$ exclusion and $\mathrm{Cu}$ accumulation in plants.

- Agronomic practices might either alleviate or exacerbate $\mathrm{Cu}$ toxicity

\section{A R T I C L E I N F O}

\section{Article history:}

Received 1 February 2016

Received in revised form

28 July 2016

Accepted 31 July 2016

Handling Editor: X. Cao

\section{Keywords:}

Copper

Rhizosphere processes

Vineyard soils

Cu toxicity

\begin{abstract}
A B S T R A C T
Viticulture represents an important agricultural practice in many countries worldwide. Yet, the continuous use of fungicides has caused copper $(\mathrm{Cu})$ accumulation in soils, which represent a major environmental and toxicological concern. Despite being an important micronutrient, $\mathrm{Cu}$ can be a potential toxicant at high concentrations since it may cause morphological, anatomical and physiological changes in plants, decreasing both food productivity and quality. Rhizosphere processes can, however, actively control the uptake and translocation of $\mathrm{Cu}$ in plants. In particular, root exudates affecting the chemical, physical and biological characteristics of the rhizosphere, might reduce the availability of $\mathrm{Cu}$ in the soil and hence its absorption. In addition, this review will aim at discussing the advantages and disadvantages of agronomic practices, such as liming, the use of pesticides, the application of organic matter, biochar and coal fly ashes, the inoculation with bacteria and/or mycorrhizal fungi and the intercropping, in alleviating $\mathrm{Cu}$ toxicity symptoms.
\end{abstract}

\section{Contents}

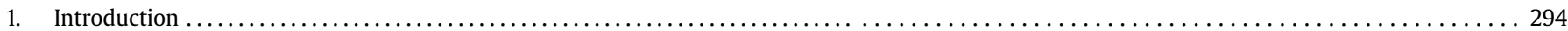

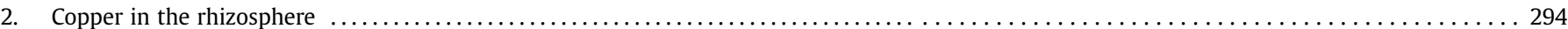

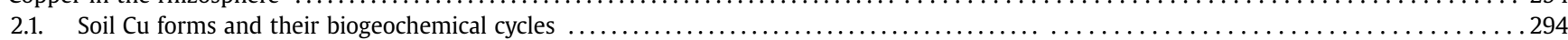



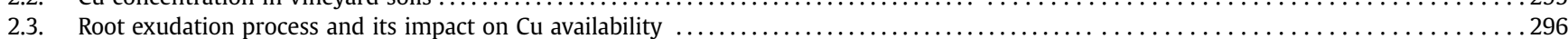

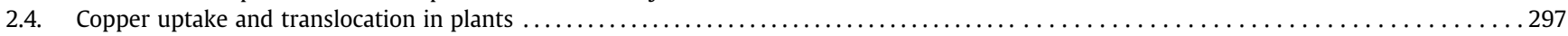

\footnotetext{
* Corresponding author.

E-mail address: tanja.mimmo@unibz.it (T. Mimmo).
} 


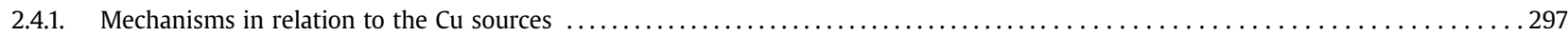

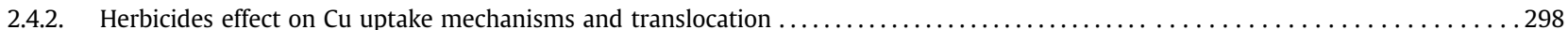

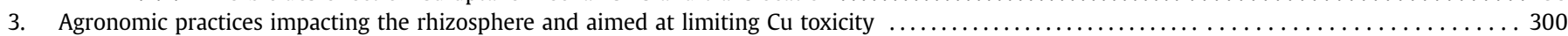

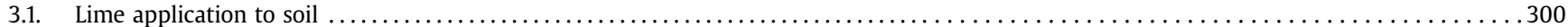

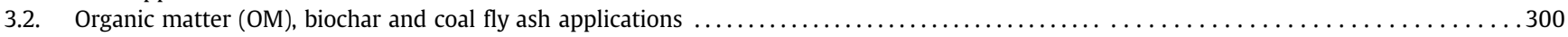

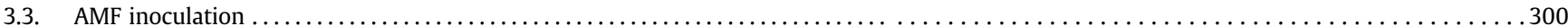

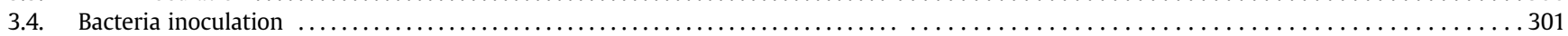

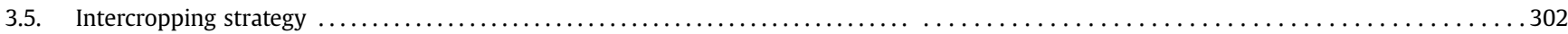

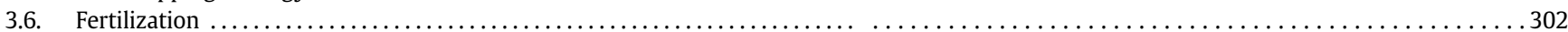

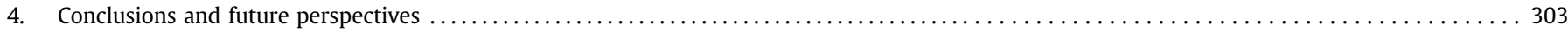

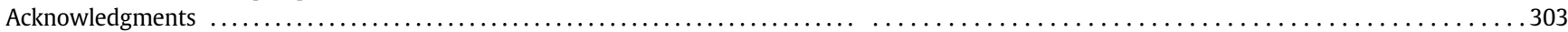

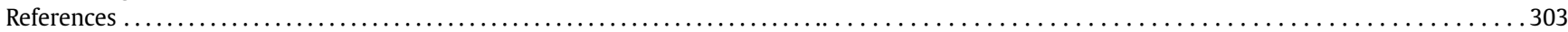

\section{Introduction}

Among the processed crops, which include all agricultural and food products that are derived from their respective primary commodities, wine is one of the most important in the world (FAOSTAT, 2012). The world viticulture regions are generally located in climatic areas that are, however, favourable to the occurrence of fungal diseases, including downy mildew (Plasmopara viticola). The regular use of copper ( $\mathrm{Cu}$ )-based fungicides (e.g. $\mathrm{Cu}$ sulfate, $\mathrm{Cu}$ oxychloride) to protect grapevine plants from these pests has led to a long-term accumulation of $\mathrm{Cu}$ in vineyard soils (particularly in the upper layers), reaching concentrations that are far higher as compared to the trace amounts that are required for healthy plant growth (Pietrzak and McPhail, 2004) and, in some circumstances, even exceeding the limits imposed in the EU for agricultural soils (Komárek et al., 2010). Besides Cu-containing fungicidal and bactericidal sprays, substantial $\mathrm{Cu}$ addition to soils can occur from the addition of contaminated wastes (Liu et al., 2007) and/or mineral- and organic-fertilizers (Xiaorong et al., 2007), including organic residues (e.g. pig and poultry manure and organic composts, Brunetto et al., 2014; Couto et al., 2015). It should be emphasized that $\mathrm{Cu}$ is an essential element for plants and, by definition, it is necessary for an organism to function properly, since it plays key roles in several biochemical and physiological processes connected to plant growth and development (Yruela, 2005). Nonetheless, depending on the concentration and on the bioavailable fraction, $\mathrm{Cu}$ could also exert toxic effects on plants. In particular, when its bioavailable concentration is very high, the growth of plants (Ambrosini et al., 2015a) and their productivity could be severely impaired. For instance, in grapevine plants grown in acidic soils, $\mathrm{Cu}$ toxicity, besides affecting plants growth and productivity (Gupta and Aten, 1993), can also worsen the quality and the nutritional value of the products (Cambrollé et al., 2013; Juang et al., 2014; Komárek et al., 2010; Tanyolaç et al., 2007; Toselli et al., 2009). For this reason, the deeper understanding of $\mathrm{Cu}$ dynamics in soil, particularly considering the complexity of rhizosphere processes driving $\mathrm{Cu}$ acquisition mechanisms by plants, could represent a prerequisite for the development of agronomic strategies aimed at limiting soil Cu-availability. These aspects are even more relevant in relation to other common agricultural practices, such as herbicide applications for weed control in vineyards.

Therefore, this review will discuss the main $\mathrm{Cu}$ processes occurring at the soil-microbe-root interface (i.e. rhizosphere) that could play a role in the tolerance mechanisms adopted by plants when grown in soil characterized by high $\mathrm{Cu}$ availability. For this purpose, $\mathrm{Cu}$ fractions in soils, mechanisms of root $\mathrm{Cu}$ uptake and its allocation in shoot as well root exudation phenomenon will be discussed in relation to the processes underlying the agronomic practices commonly adopted, also considering the role that herbicides or their residues in the soil could exert. Strategies to improve agronomic practices aimed at mitigating $\mathrm{Cu}$ toxic effects will also be discussed.

\section{Copper in the rhizosphere}

It is well known that the $\mathrm{Cu}$-available fraction for plants strongly depends on mineral and organic forms in the soil and on biogeochemical cycles, which the different $\mathrm{Cu}$ sources undergo. Moreover, in the rhizosphere these cycles are strongly influenced by the intensive interactions between roots and microorganisms, which, in turn, shape the mineral and organic $\mathrm{Cu}$ fractions. In addition, the amount of $\mathrm{Cu}$ absorbed by plants depends on both its availability in the rhizosphere and the functionality of the protein systems committed to the nutrient acquisition at root level and, then to the allocation into shoot tissues. In other words, $\mathrm{Cu}$ forms, which can be taken up, are closely dependent on the selectivity of those proteins, which mediate nutrients' transport across the plasma membranes.

\subsection{Soil $\mathrm{Cu}$ forms and their biogeochemical cycles}

Copper is a metallic element and its natural concentration in soil depends on its concentration in rocks. The average $\mathrm{Cu}$ concentration in soils registered worldwide ranges from 6 to $80 \mathrm{mg} \mathrm{kg}^{-1}$. Soils with a $\mathrm{Cu}$ concentration lower than $8 \mathrm{mg} \mathrm{kg}^{-1}$ may because of the onset of Cu deficiency symptoms in crops (McBride, 1994).

The distribution of $\mathrm{Cu}$ between solid phase and soil solution depends on precipitation/dissolution, adsorption/desorption and redox reactions (Fig. 1). In the soil solution, Cu may be in free form as $\mathrm{Cu}^{2+}$ or, in most cases, complexed. The complexation may occur with either inorganic anionic binders or organic molecules. The formation of stable complexes in the soil solution can delay the adsorption of $\mathrm{Cu}$ with functional groups on the surface of reactive particles (Alleoni et al., 2005; Sparks, 2003). In the solid phase, $\mathrm{Cu}$ can be sorbed through mechanisms such as ion exchange (nonspecific adsorption), specific adsorption and complexation with soil organic matter (Alloway, 1995; Sposito, 1989). Non-specific adsorption is weak and unstable. This type of adsorption weakly affects the availability of $\mathrm{Cu}$. In this type of sorption, $\mathrm{Cu}$ can retain its internal hydration sphere and a high degree of rotational mobility on exchange sites (Alleoni et al., 2005; McBride, 1979). In specific adsorption on functional groups of inorganic particles, the metal partially or completely loses its hydration water forming an inner sphere complex with either $\mathrm{OH}^{-}$or a $\mathrm{H}_{2} \mathrm{O}$ molecule bound to a metal ion of the crystalline lattice on the surface of $\mathrm{Fe}, \mathrm{Mn}$ and $\mathrm{Al}$ oxides, non-crystallized aluminosilicates and edges of clay minerals (Alleoni et al., 2005; Bradl, 2004; Ferreira et al., 2014).

The nature of $\mathrm{Cu}$ interactions with soil components has been 


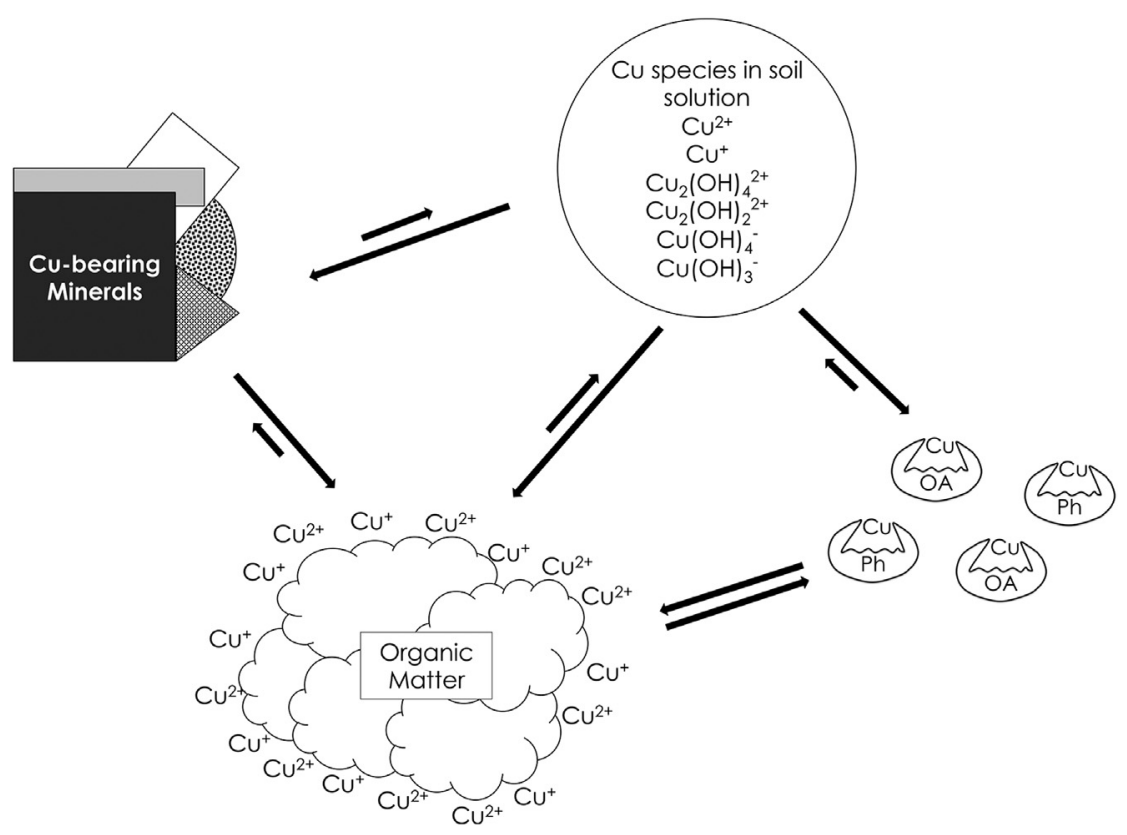

Fig. 1. Cu species in soil. Equilibria determining the $\mathrm{Cu}$ availability for living organisms. $\mathrm{OA}=\mathrm{Organic}$ Acids; $\mathrm{Ph}=\mathrm{Phenolic} C \mathrm{Compounds}$.

elucidated in the last years with the use of synchrotron X-ray techniques, especially X-ray absorption spectroscopy (XAS). With an X-ray multi-analytical approach, Strawn and Baker (2009) studied five Cu-contaminated soils with different characteristics and $\mathrm{pH}$ (from 5.2 to 7.1). They found that in all soils, $\mathrm{Cu}$ exists predominantly as $\mathrm{Cu}$-soil organic matter complexes (Cu-SOM) in the form of five membered ring chelates, despite differences in soil mineralogy, organic matter (OM) content, Cu sources, contamination date, and whether the soils were contaminated in situ or spiked in the laboratory. Therefore, especially in acid and neutral soils, the biogeochemistry of $\mathrm{Cu}$ is largely controlled by its interaction with natural OM, not so much because of OM abundance and polyfunctional character, as for its remarkable affinity towards $\mathrm{Cu}(\mathrm{II})$ in comparison to other divalent cations (Manceau and Matynia, 2010).

Using X-ray absorption near edge spectroscopy (XANES) and extended X-ray absorption fine structure (EXAFS) spectroscopy, and $\mathrm{Cu}$-glutamate as the best-fit structural analog, Karlsson et al. (2006) showed that at $\mathrm{pH} 4.8-6.3 \mathrm{Cu}$ (II) forms a five-membered chelate ring with one amino nitrogen $\left(\alpha-\mathrm{NH}_{2}\right)$ or alcohol oxygen $(\alpha-\mathrm{OH})$ and one carboxylate oxygen from an $\alpha$-substituted aliphatic carboxylic structure. Manceau and Matynia (2010), exploiting XAS spectroscopy along with supporting thermodynamic equilibrium calculations and structural and steric considerations, showed evidence at $\mathrm{pH} 4.5$ and 5.5 for a five-membered $\mathrm{Cu}$ (malate) $)_{2}$-like ring chelate at 100-300 ppm Cu concentration, and a six-membered

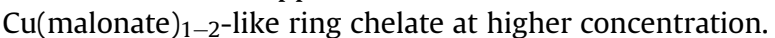

Because of the high affinity of $\mathrm{Cu}$ for soil colloids and especially $\mathrm{SOM}, \mathrm{Cu}$ is rated a low-mobile element in near-neutral soils. For this reason, farmers have been able to apply large amounts of $\mathrm{Cu}$ salts to organic soils over time without, in general, causing toxicity to crops (McBride, 1994).

In more alkaline soils, while free $\mathrm{Cu}^{2+}$ solubility is exceedingly low, soluble complexes of $\mathrm{Cu}$ (hydroxy-, carbonate-, and OMcomplexes) may form, thus increasing the total soil fraction of mobile Cu. Consequently, mobility of this nutrient may be rather high in alkaline conditions (McBride, 1994). To date, there are not detailed studies using XAS on $\mathrm{Cu}$ speciation in alkaline soils with a low content of OM, like those that can be found in arid and semiarid regions. A survey on 21 calcareous agricultural soils from
Western Iran with a pH ranging from 6.8 to 7.9 showed that, on average, about $56 \%$ of $\mathrm{Cu}$ remained in the residual fraction after sequential extractions while about $20 \%$ was associated to SOM (Khanlari and Jalali, 2008). Similarly, in a vineyard calcareous soil with $\mathrm{pH} 7.8$, it has been observed that natural $\mathrm{Cu}$ is preferentially retained in the residual fraction, which is stable or unavailable (Herrero-Hernández et al., 2011). It is likely that (hydr)oxides or hydroxy-carbonates $\mathrm{Cu}$-forms may be the most abundant forms of $\mathrm{Cu}$ in these conditions (McBride, 1994). Moreover, FernándezCalviño et al. (2009) investigated soils from 170 vineyards in Spain treated for long time with $\mathrm{Cu}$-based fungicides and possessing a $\mathrm{pH}$ between 4.9 and 6.6. From this survey they found that $\mathrm{Cu}$ was present mainly in less mobile fractions, with about $48 \%$ bound to soil organic matter, $15 \%$ associated to amorphous inorganic materials, $12 \%$ to crystalline $\mathrm{Fe}$ and $\mathrm{Al}$ oxides, and $23 \%$ as residual.

These pieces of information clearly show that $\mathrm{Cu}$ is rather stable in soil and its availability depends on the nature of the binder (particularly $\mathrm{OM}, \mathrm{Fe}, \mathrm{Al}$, and $\mathrm{Mn}$ minerals and (hydr)oxides) and its relative amount as well as on carbonates, soil $\mathrm{pH}$ and cation exchange capacity (CEC) (Brunetto et al., 2014; Couto et al., 2015; Fernández-Calviño et al., 2009). Copper adsorption in soil occurs primarily in the most avid binding sites, especially OM, and the remaining is redistributed into fractions that are held with less energy and that consequently exhibit a higher availability and mobility in the soil profile.

\subsection{Cu concentration in vineyard soils}

From a survey on the literature published worldwide about $\mathrm{Cu}$ concentration in the upper layers of vineyard soils, Komárek et al. (2010) observed that $\mathrm{Cu}$ concentrations in superficial horizons often exceed $200 \mathrm{mg} \mathrm{kg}^{-1}$ and that the highest $\mathrm{Cu}$ concentrations are present in the upper layers of soil profiles. Most of these values exceed the warning and critical legislative limits valid in most Countries around the World. For example, the predicted no effect concentration (PNEC) of $\mathrm{Cu}$ in soils in the EU (estimated in the EU Risk Assessment on $\mathrm{Cu}$ ) ranges from 20 to $200 \mathrm{mg} \mathrm{Cu} \mathrm{kg}$ depending on soil properties (Ruyters et al., 2013 and references 
therein). In a recent paper by Tóth et al. (2016) on the concentration of heavy metals in agricultural soils of the European Union, a threshold of $100 \mathrm{mg} \mathrm{kg}^{-1}$ was considered for $\mathrm{Cu}$, with lower and higher guideline values set at $150 \mathrm{mg} \mathrm{kg}^{-1}$ and $200 \mathrm{mg} \mathrm{kg}^{-1}$, respectively. Exceptionally high concentrations of $\mathrm{Cu}$ in vineyard soils have been observed in France (above $1000 \mathrm{mg} \mathrm{kg}^{-1}$, FloresVélez et al., 1996) and in Brazil (above $3000 \mathrm{mg} \mathrm{kg}^{-1}$, Mirlean et al., 2007). Toxic effects of $\mathrm{Cu}$ on the microbial communities in vineyard soils have been observed above total concentrations of 150-200 mg Cu kg-1 (Fernández-Calviño et al., 2010).

However, in a survey by Ruyters et al. (2013) on six established European vineyards, no $\mathrm{Cu}$ toxicity to plants, microbial processes and invertebrates was observed in vineyard soil samples at $\mathrm{Cu}$ concentrations well above European Union limits protecting the soil ecosystem. This is likely due to a decreased Cu bioavailability in vineyard soils compared to $\mathrm{Cu}$-spiked soils. In fact, according to these authors, on average, 3.2 times larger $\mathrm{Cu}$ might be dosed in vineyards than in spiked soils to obtain a $10 \%$ inhibition, and is larger than the factor of 2.0, which is proposed in the generic risk assessment of $\mathrm{Cu}$ in soil. According to these data, in vineyard soils, $\mathrm{Cu}$ toxicity limits are not easily definable and, in principle, could be set at higher values than in other $\mathrm{Cu}$-contaminated soils.

\subsection{Root exudation process and its impact on $\mathrm{Cu}$ availability}

The rhizosphere is characterized by radial and longitudinal fluxes and gradients of both organic and inorganic compounds that shape rhizosphere processes (Mimmo et al., 2014). These latter, in turn, are able to influence considerably the transformations and flows of nutrients from soil to plant (Badalucco and Nannipieri, 2007). For these reasons, they are considered to be the bottleneck of nutrient mobilization in soil and subsequent acquisition by plants and, therefore, of crop yield. On the other hand, the ability of such processes to mobilize nutrients from insoluble sources in the soil might also be reflected in increased bioavailable fractions of toxic elements and/or of those nutrients capable to exert toxic effects on plants when occurring at a very high availability (Valentinuzzi et al., 2015). Rhizosphere processes and effects on plants are governed mainly by the release of root exudates, which comprise both low- and high-molecular weight inorganic and organic compounds, as for instance protons, carbohydrates, organic acids, amino acids, phytosiderophores (PS), phenolic compounds and enzymes (Dakora and Phillips, 2002). Root exudates are fundamental for the induction of changes in the chemical, physical and biological characteristics of the rhizosphere, and are involved in paramount pedogenic and rhizosphere processes affecting functions as 1) the modulation of elements bioavailability in the rhizosphere (Fe, P, Zn; Dakora and Phillips, 2002), 2) the root protection against toxic metals ( $\mathrm{Al}, \mathrm{Zn}, \mathrm{Cd}$; Jones, 1998) and 3) the shaping of the rhizosphere microbiome (Pii et al., 2016, 2015).

Indeed, root exudates, especially those with a low molecular weight, can be used by microorganisms as easily accessible source of carbon in the rhizosphere, where the concentration of such compounds is usually higher as compared to bulk soil (Hinsinger et al., 2009). In addition, root exudates can also play a role as powerful chemo-attracttors, stimulating the colonization of the rhizosphere by selected microbial strains, which might display plant growth-promoting traits. These properties are very often related to the ability of bacteria of either producing hormone-like compounds, which increase the growth of the root system, or protecting the host against pathogens attacks or enhancing the bioavailability of mineral macro- and micro-nutrients (e.g. N, P and Fe) (Pii et al., 2015).

With respect to the biogeochemical cycle of $\mathrm{Cu}$ in soil, it is interesting to note that the bioavailable fractions of $\mathrm{Cu}$ are considerably tailored by the biological activities of root, i.e. release of exudates and in particular of low-molecular-weight organic compounds. This release is strictly dependent on plant species and environmental conditions, both in terms of concentration and quality (Jones, 1998; Mimmo et al., 2011), and this phenomenon has been mainly studied for its potentialities to modulate microbial growth, mobilize insoluble nutrients (e.g. P, Fe, Zn) and detoxify harmful heavy metals (Dakora and Phillips, 2002; Pii et al., 2015; Weisskopf et al., 2006). In this latter case, the exudates, mainly carboxylic and phenolic acids, are thought to chelate heavy metals, as for instance $\mathrm{Cu}$, either in the rhizosphere or in the apoplast, preventing the movement across the membranes to the root symplasts (Kochian et al., 2004). Therefore, the qualitative and quantitative pattern of root exudates may play a fundamental role in alleviating $\mathrm{Cu}$ toxicity in plants. Low-molecular-weight organic compounds might be involved in both external and internal tolerance mechanisms. In fact, the so-called excluder plants prevent the bioaccumulation of heavy metals in plant tissues by either blocking the uptake in the roots (Lux et al., 2011) or by active efflux pumps (Van Hoof et al., 2001). Root exudates released by excluder plants might have a role in immobilizing and decreasing the bioavailability of toxic metals; this mechanism might be further influenced by the activity of rhizosphere microorganisms. These plant species might thereby also act as phytostabilizators in contaminated soils (Lorestani et al., 2013). On the other hand, hyperaccumulator plants adopt an internal mechanism and can accumulate high concentrations of heavy metals in their shoot tissues (up to several per cent of the shoot dry mass) without suffering any stress (Clemens, 2001). In these species, the release of organic ligands may contribute to an enhanced mobility and replenishment of metals in the rhizosphere (Wenzel et al., 2003).

For instance, several studies have highlighted that citrate, oxalate and malate are the most common and effective organic acids in binding metals and metalloids, such as arsenic, chromium, cadmium and lead (Jones and Darrah, 1994; Magdziak et al., 2011). On the other hand, very little research has been carried out on the role of organic acids in alleviating $\mathrm{Cu}$ stress in plants. Early evidences showed that oxalate was exuded by coniferous trees Pinus and Picea in response to Cu stress (Ahonen-Jonnarth et al., 2000; Heim et al., 2001). More recently, Qin et al. (2007) observed that, besides oxalate, poplar trees exuded formate and malate in a concentration that is directly dependent on the concentration of the $\mathrm{Cu}$ bioavailable fraction. In addition, it was also observed that the exudation of organic anions was accompanied by a release of inorganic cations (i.e. $\mathrm{K}^{+}, \mathrm{Ca}^{2+}$ and $\mathrm{Mg}^{2+}$ ) (Qin et al., 2007). Research carried out on metallophytes, namely Oenothera picensis and Imperata condensata, grown in culture media supplemented with toxic concentration of $\mathrm{Cu}$, revealed that in these cases citrate and oxalate were predominantly released (Meier et al., 2012) Also, a large amount of succinic acid was also detected in the root exudates, suggesting that this could be an unspecific response towards $\mathrm{Cu}$-induced stress, since the complex Cu-succinate has a much lower stability constant as compared to those of $\mathrm{Cu}$-citrate and $\mathrm{Cu}$ oxalate (Table 1) (Borges et al., 2005). Yet, the metallophytes were also shown to respond towards an excess of $\mathrm{Cu}$ by releasing phenolic compounds (i.e. cinnamic acid, coumaric acid and catechin), which can stabilize the heavy metal with high affinity (Meier et al., 2012). Furthermore, a strong release of tartaric acid as well as the amino acids valine and serine has been described for the $\mathrm{Cu}$ tolerant species Ricinus communis L. (Huang et al., 2015). On the contrary, Zhang et al. (1989) discovered an enhanced PS production and release in $\mathrm{Cu}$-deficient grasses, although up to date it is still uncertain whether PS release is a specific response to Cu deficiency or a consequence of a series of internal events linked to an impairment of Fe utilization that was observed in these plants 
Table 1

Acid dissociation constants of organic compounds and stability constants of metal chelates.

\begin{tabular}{|c|c|c|c|c|c|c|c|c|}
\hline & \multirow[t]{2}{*}{ Acid dissociation constant $(\log \mathrm{K})$} & \multicolumn{7}{|c|}{ Stability constant (logK) of different metal chelate } \\
\hline & & $\mathrm{Ca}$ & $\mathrm{Cu}$ & $\mathrm{Fe}(\mathrm{III})$ & Mn & $\mathrm{Ni}$ & $\mathrm{Sr}$ & Zn \\
\hline Citric acid & $\begin{array}{l}3.14^{\mathrm{a}} \\
4.77^{\mathrm{a}} \\
6.39^{\mathrm{a}}\end{array}$ & $3.5^{\mathrm{b}}$ & $6.1^{\mathrm{b}}$ & $11.85^{b}$ & $3.2^{\mathrm{b}}$ & $4.8^{\mathrm{b}}$ & $2.8^{\mathrm{b}}$ & $4.5^{\mathrm{b}}$ \\
\hline Formic acid & $3.75^{\mathrm{a}}$ & $0.80^{\mathrm{b}}$ & $1.98^{\mathrm{b}}$ & $3.1^{\mathrm{b}}$ & & & $0.66^{\mathrm{b}}$ & $0.60^{b}$ \\
\hline Fumaric acid & $\begin{array}{l}3.02^{\mathrm{a}} \\
4.38^{\mathrm{a}}\end{array}$ & $2.00^{\mathrm{b}}$ & $2.51^{\mathrm{b}}$ & & $0.99^{\mathrm{b}}$ & & $0.54^{\mathrm{b}}$ & \\
\hline Malic acid & $\begin{array}{l}3.40^{\mathrm{a}} \\
5.11^{\mathrm{a}}\end{array}$ & $1.80^{\mathrm{b}}$ & $3.4^{\mathrm{b}}$ & & $2.24^{\mathrm{b}}$ & & $1.45^{\mathrm{b}}$ & $2.80^{b}$ \\
\hline Malonic acid & $\begin{array}{l}2.83^{\mathrm{a}} \\
5.69^{\mathrm{a}}\end{array}$ & $1.8^{\mathrm{c}}$ & $5.04^{c}$ & $8.12^{c}$ & $2.5^{\mathrm{c}}$ & $3.24^{c}$ & $1.34^{\mathrm{c}}$ & 2.91 \\
\hline Oxalic acid & $\begin{array}{l}1.23^{\mathrm{a}} \\
4.19^{\mathrm{a}}\end{array}$ & $3.0^{\mathrm{b}}$ & $6.3^{\mathrm{b}}$ & $9.4^{\mathrm{b}}$ & $3.9^{b}$ & $5.16^{\mathrm{b}}$ & $2.54^{\mathrm{b}}$ & $4.9^{b}$ \\
\hline Succinic acid & $\begin{array}{l}4.16^{\mathrm{a}} \\
5.61^{\mathrm{a}}\end{array}$ & $1.20^{\mathrm{b}}$ & $3.3^{\mathrm{b}}$ & $7.49^{\mathrm{b}}$ & $2.11^{\mathrm{b}}$ & $2.36^{\mathrm{b}}$ & $0.9^{\mathrm{b}}$ & $1.78^{b}$ \\
\hline Tartaric acid & $\begin{array}{l}2.98^{\mathrm{a}} \\
4.34^{\mathrm{a}}\end{array}$ & $1.80^{\mathrm{b}}$ & $3.2^{\mathrm{b}}$ & $7.49^{\mathrm{b}}$ & & $3.78^{b}$ & $1.94^{\mathrm{b}}$ & $2.68^{\mathrm{b}}$ \\
\hline Glutamic acid & $\begin{array}{l}2.13^{\mathrm{a}} \\
4.31^{\mathrm{a}}\end{array}$ & $1.43^{\mathrm{b}}$ & $7.85^{\mathrm{b}}$ & & $3.3^{\mathrm{b}}$ & $5.9^{\mathrm{b}}$ & $1.37^{\mathrm{b}}$ & $5.45^{b}$ \\
\hline Glycine & $\begin{array}{l}2.35^{\mathrm{a}} \\
9.78^{\mathrm{a}}\end{array}$ & $1.43^{\mathrm{b}}$ & $8.22^{\mathrm{b}}$ & $10.0^{\mathrm{b}}$ & $3.2^{\mathrm{b}}$ & $6.1^{\mathrm{b}}$ & $0.91^{\mathrm{b}}$ & $5.16^{b}$ \\
\hline Serine & $\begin{array}{l}2.19^{\mathrm{a}} \\
9.21^{\mathrm{a}}\end{array}$ & $1.43^{\mathrm{b}}$ & & $9.2^{\mathrm{b}}$ & & $5.44^{\mathrm{b}}$ & & \\
\hline Valine & $\begin{array}{l}2.29^{\mathrm{a}} \\
9.74^{\mathrm{a}}\end{array}$ & & $7.92^{\mathrm{b}}$ & $9.6^{\mathrm{b}}$ & $2.84^{\mathrm{b}}$ & $5.37^{\mathrm{b}}$ & & $5.0^{\mathrm{b}}$ \\
\hline
\end{tabular}

a (Haynes, 2010).

b http://www.coldcure.com/html/stability_constants.html.

c (Martell et al., 2004).

(Chaignon et al., 2002).

By examining the stability constants of complexes formed between $\mathrm{Cu}$ and root exudates (Table 1), it is clear that, some of them (e.g. citrate, formate, oxalate, succinate) display a higher affinity for FeIII as compared to $\mathrm{Cu}$. Therefore, the presence of FeIII in high concentrations might reduce the effectiveness of these compounds in alleviating $\mathrm{Cu}$ toxicity.

However, most of these studies describing the different qualitative and quantitative patterns of root exudates triggered by $\mathrm{Cu}$ toxicity were carried out in hydroponic solutions, whilst it has been showed that the exudation processes might be considerably different in soil-grown plants (Oburger et al., 2014). Hence, future researches should focus on field-like conditions, thus bridging micro- and macro-scale studies but considering also other aspects that are generally present in the field scale as the agrochemicals and/or their residues. In fact, it has already been shown that herbicides application can alter the profile of exudates released by roots in the rhizosphere (Damin et al., 2010; Kremer et al., 2005; Manderscheid et al., 2005) affecting considerably, thus, the capacity of roots to shape the rhizosphere. However, despite these evidences, a too limited number of studies aiming at investigating the effect of herbicides at this level have been carried out. Therefore, as it will be discussed later, it is still an open question how this class of agrochemicals, and particularly those used in post-emergence or characterized by a long persistence in soils, can modify the characteristics of the rhizosphere soil and then interfere with $\mathrm{Cu}$ acquisition process, particularly in conditions where, for anthropic actions, a long-term accumulation of $\mathrm{Cu}$ in the upper layers occurred.

\subsection{Copper uptake and translocation in plants}

\subsubsection{Mechanisms in relation to the $\mathrm{Cu}$ sources}

As also stated before, the mechanisms of $\mathrm{Cu}$ trans-membrane transport in root share the access path for the flow of the nutrient from the soil solution to the plant tissue in either growth conditions of low, balanced or excessive availability. However, the selectivity of these mechanisms, at least at some levels, can restrict

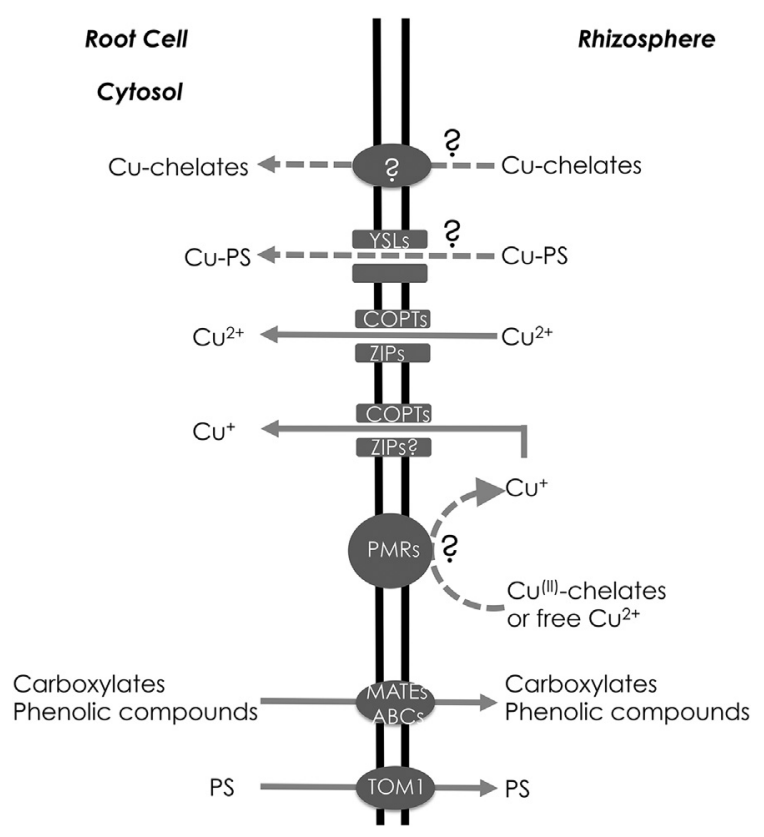

Fig. 2. Schematic representation of the putative mechanisms involved in $\mathrm{Cu}$ acquisition in plants. Arrows with continuous lines stand for characterized $\mathrm{Cu}$-uptake systems. Dashed lines and question marks highlight putative processes. $\mathrm{PS}=$ phytosiderophores; YSLs = yellow stripe-like proteins; COPTs $=$ copper transporters, e.g. COPT1; ZIP $=\mathrm{Zn} / \mathrm{Fe}$ permease proteins, e.g. IRT1; PMRs = plasma membrane-bound reductases, e.g. Fe-chelate reductases; MATEs = multidrug and toxic compound extrusion proteins, e.g. AtMATE1, PEZ1; ABCs = ATP-binding cassette transporters, e.g. ABCG37/PDR9; TOM1 = protein involved in PS released, limited to grass species. 
the number of $\mathrm{Cu}$ forms that can be used by roots as $\mathrm{Cu}$ sources (Fig. 2). Analyzing this aspect from an opposite point of view, it is established that there are $\mathrm{Cu}$ forms in soil solution which cannot be used by transporter proteins and therefore they do not represent a risk when the crops are grown in conditions of very high abundance of these plant-unavailable $\mathrm{Cu}$ forms. The understanding of these mechanisms of $\mathrm{Cu}$ acquisition and, in particular, of their functional characteristics can play a relevant role in order to define agronomic practices aimed at limiting the toxic effect of $\mathrm{Cu}$. This aspect is particularly relevant when vineyard soils exposed for a long period to a regular deposition of Cu-based fungicides or deriving from plant tissues treated with these agrochemicals, are considered. Similarly, mechanisms of $\mathrm{Cu}$ homeostasis within tissues and within cells can be relevant for the detoxification from $\mathrm{Cu}$, once taken up by the plants.

The mechanisms of $\mathrm{Cu}$ transport in roots (micronutrient uptake) have been characterized in the last two decades (Sancenón et al., 2003; Wintz et al., 2003). In particular, Cu transport protein 1 (COPT1) is thought to mediate most of the $\mathrm{Cu}$ uptake into cells, whereas other members of this protein family may mediate intracellular transport of Cu (Sancenón et al., 2003). However, other transporters seem to be involved in this process, as for instance members of the Zn/Fe permeases (ZIPs) family, ZIP2 and ZIP4, have been shown to function as Cu-transporters in Arabidopsis thaliana (Wintz et al., 2003); yet, it is well established that the main Fe transporter (IRT1) can also mediate the uptake of $\mathrm{Cu}, \mathrm{Cd}, \mathrm{Co}$ and $\mathrm{Zn}$ (Korshunova et al., 1999). Moreover, Cu-PS might be taken up by grass roots, even though with a much lower affinity than Fe-PS, via yellow stripe-like (YSL) proteins (Marschner, 2011; Wintz et al., 2003). This family of proteins seems to be also implicated in the transport of the chelate Cu-nicotianamine (Wintz et al., 2003), which is presumably involved in the translocation of this micronutrient (allocation to the shoot). A schematic representation of the putative mechanisms involved in $\mathrm{Cu}$ acquisition is summarized in Fig. 2.

Other proteins have been shown to be involved in the transport of $\mathrm{Cu}$ across membranes; some P1B-type ATPase (HMA) transporters can transport either $\mathrm{Cu}^{2+}$ or $\mathrm{Cu}^{+}$(Zimmermann et al., 2009) playing a role mostly in the $\mathrm{Cu}$-allocation into different organelles or translocation into other tissues (Di Donato et al., 2004). Interestingly, $\mathrm{Cu}$ is transported in the xylem exclusively in complexed form (Graham, 1979), most likely with organic nitrogen ligands, as for instance amino acids (Kochian, 1991) and nicotianamine. In fact, $\mathrm{Cu}$ has a high affinity for peptide and sulfhydryl groups, as well as for carboxylic and phenolic groups. Therefore, in cells and in the xylem sap, almost $100 \%$ of the $\mathrm{Cu}$ is present in complexed/bound form and this high percentage of binding is also retained under conditions of excessive Cu supply (Graham, 1979; Liao et al., 2000a, 2000b; Pich and Scholz, 1996; White et al., 1981). This suggests that even under toxic conditions, plants have mechanisms to regulate complexation of $\mathrm{Cu}$ within the xylem sap and, hence, minimize potential damage caused from high concentrations of free $\mathrm{Cu}$ ions (Welch and Shuman, 1995).

On the basis of these studies, it appears evident that in soil solution, where more than $98-99 \%$ of the $\mathrm{Cu}$ is present in complexed form (Marschner, 2011), the Cu sources usable by roots for the nutrient acquisition are mainly the ionic one $\left(\mathrm{Cu}^{2+}\right.$ and/or $\left.\mathrm{Cu}^{+}\right)$and, limited to the grasses, also the complexed form with PS, although it is still not clear the relative contribution between the different forms. In this latter group of plants, the utilization of two $\mathrm{Cu}$ forms (ionic and complexed with PS) could coexist, as documented for $\mathrm{Zn}$ (Von Wiren et al., 1996). However, up to date the possibility that roots can absorb also other $\mathrm{Cu}$ sources (e.g. soluble $\mathrm{Cu}$-complexes with low-molecular-weight organic molecules) should not be totally excluded, considering also the limited literature available on this aspect. Nonetheless, if this phenomenon occurs, the idea is that its role in the root acquisition process of $\mathrm{Cu}$ would be rather limited. Among the different fractions of $\mathrm{Cu}$ in the soil, the soluble one is generally defined as being available, thus it is clear that this definition is not completely appropriate. In fact, it overestimates the $\mathrm{Cu}$ forms actually usable by the plants and includes fractions (e.g. complexes with organic compounds of low-molecular-weight such as organic acids, amino acids, etc.) that could instead be the result of the operation of strategies aimed at excluding and/or limiting the $\mathrm{Cu}$ uptake process at the root level with $\mathrm{Cu}$ excess.

\subsubsection{Herbicides effect on $\mathrm{Cu}$ uptake mechanisms and translocation}

It is widely known that herbicides are commonly used in agricultural practices in order to limit the competition for nutrients, water and light between weeds and crops. Such weeds control is often applied also in orchards, including vineyards. However, the interference of herbicides (or their residues) in the functionality of nutrient uptake mechanisms in non-target plants (crops) has been recently demonstrated. A very clear example is the impairment on Fe-acquisition mechanism determined by glyphosate in soybean (Bellaloui et al., 2009) and by terbuthylazine in barley (Del Buono et al., 2015). In the first case, the impairment is on the root transmembrane protein underlying the $\mathrm{Fe}^{\mathrm{III}}$-chelate reduction before its transporter-dependent flux across the membrane, while in the second the effect appear to be more focused on sulfur reductive assimilation pathway, prerequisite for the synthesis and release of PS. A similar depressive effect of glyphosate as that described for Fe in soybean plants has been shown by Eker et al. (2006) in sunflower plants, where Mn acquisition was impaired by the presence of this agrochemical.

With respect to $\mathrm{Cu}$, it has been demonstrated that chlorsulfuron (a sulfonylurea used in pre- and post-emergence stages) depressed the Cu concentration in non-target wheat plants (Tang and Robson, 2000). This effect has been ascribed to an impact in the root capacity to take up Cu (Robson and Snowball, 1990) or, more in general, to an impairment in the root functionality as a consequence of the negative effect on the growth and the geometry of this tissue (Dong et al., 1995). A similar effect was also recorded in non-target Triticum aestivum and $T$. rigidum plants treated with chlorsulfuron, with an impact not only restricted to Cu but also to $\mathrm{Zn}$ and Mn acquisition (Rengel and Wheal, 1997).

In this general context, an effect of herbicides on the transmembrane electrochemical gradient governing the movements of solutes (including nutrients) across the membranes could be of relevance in the nutrient acquisition by roots. In this respect, Shimabukuro and Hoffer (1994) found in non-target oat plants that the herbicide diclofop-methyl, after the hydrolysis to its acidic active form, caused a membrane depolarization via an enhanced plasma membrane permeability to protons. Also other herbicides (dictofop, hydroxydiclofop, CGA 82725, haloxyfop-methyl, haloxyfop, bentazon, dinoseb, 4-hydroxy CIPC, and 2-hydroxy CIPC) exhibited this mode of interference in oat coleoptiles (Wright, 1994). However, some studies showed that glyphosate and atrazine applied as foliar sprays induced a higher $\mathrm{Cu}$ leaf accumulation than in untreated plants (Correia and Dos Santos, 2013). This report clearly indicates that herbicides might also influence $\mathrm{Cu}$ allocation at the leaf level and/or be involved in their homeostasis.

2.4.2.1. Cu toxicity in plants and soil microorganisms; effects and response strategies. As stated before, although $\mathrm{Cu}$ is an essential nutrient both in plants and in microbial cells, when its concentration is too high, a series of toxic phenomena occurs and strategies aimed at limiting its harmful effects are adopted.

Concerning, root apices, the first target of $\mathrm{Cu}$ nutritional disorder in the soil, generally become shorter and thicker for changes in 
the cell wall formation (Ambrosini et al., 2015a). Moreover, the number of lateral roots often increases with also an evident plasmolysis of some epidermis cells. Taken together, these phenomena are able to cause a clear contraction of the root density (Chen et al., 2013; Juang et al., 2014, 2011; Zhang et al., 2014) which, in turn, has an impact in the root capacity to acquire nutrients and water; in these conditions, also the root capability to take up other nutrients is impaired inducing, for example, symptoms of deficiency (Ambrosini et al., 2015b). Considering in particular the Cu acquisition process, it is interesting to note that living organisms have developed a complex homeostatic system to regulate the acquisition and use of $\mathrm{Cu}$ (Sancenón et al., 2003). In excess of $\mathrm{Cu}$, the $\mathrm{Cu}$ uptake is down regulated and the synthesis of compounds, such as metallothioneins or phytochelatins, is induced (Mukherjee et al., 2006). Both these polypeptides are able to bind $\mathrm{Cu}$ in order to reduce its availability in the cytosol and thus to alleviate its toxic effects. The compartmentalization of heavy metals in the apoplast of roots or in organelles such as the vacuole (Chaignon and Hinsinger, 2003) is also used for this purpose.

At the rhizosphere level, roots can modify the $\mathrm{pH}$ value of the external soil environment as a consequence of a preferential uptake of cations or anions. When anions prevail (as after nitrate fertilization), there is an increase in $\mathrm{pH}$ values favouring, for example, $\mathrm{Cu}$-complexing processes. As a consequence, the proportion of freemetal species of $\mathrm{Cu}$ in the solution is restricted and, then, also its toxicity to plants is reduced (Brimecombe et al., 2001). Also the organic acids (such as citric acid, malic acid, fumaric acid, oxalic acids, among others) released by roots, as described also for vine plants (Covarrubias, 2012), or derived from OM decomposition, promoted by soil microorganisms (Oburger et al., 2009; Pii et al., 2015), can bind the $\mathrm{Cu}$ thanks to their high affinity binding with heavy metals (De Conti et al., 2016; Jones and Darrah, 1994). This latter phenomenon, together with the rhizosphere alkalinization, is able to alter the $\mathrm{Cu}$ solubility (modifying the distribution of $\mathrm{Cu}$ chemical species) thus reducing the toxic potential of the heavy metal to crops (Meier et al., 2012; Pérez-Esteban et al., 2014). However, when the availability of $\mathrm{Cu}$ is even higher and the strategies adopted by the plants are unable to enough control $\mathrm{Cu}$ availability, $\mathrm{Cu}$ can cause necrosis and, if the stress is prolonged, plant death (Marschner, 2011; Miotto et al., 2013; Toselli et al., 2009).

At the leaf level, $\mathrm{Cu}$ disorder causes a decrease in the pigment concentration with a subsequent drop of the photosynthetic rate (Cambrollé et al., 2015, 2013). A typical leaf symptom of this toxicity is the interveinal foliar chlorosis, partially ascribed to the negative effect on Fe acquisition exerted by Cu excess (Ouzounidou, 1995; Yau et al., 1991). As a consequence, plants subjected to Cu toxicity are generally smaller with also an accumulation of carbohydrates and starch at the leaf level for the lower demand of energy for the biomass production (Alaoui-Sossé et al., 2004). Furthermore, the high levels of $\mathrm{Cu}$ in these tissues induce oxidative stress as a consequence of an increased concentration of reactive oxygen species (ROS). Among the damages caused by ROS, peroxidation of membrane lipids is one of the worst for cell survival (Apel and Hirt, 2004; Miotto et al., 2013; Yruela, 2005). Moreover, in addition to its capability to bind to proteins and amino acids, $\mathrm{Cu}$ can also replace other metals from their natural binding sites, which increase $\mathrm{Cu}$ toxicity (Halliwell and Gutteridge, 1990). As described before, also at the leaf level the synthesis of metallothioneins or phytochelatins is induced by the plant exposure to $\mathrm{Cu}$ excess (Mukherjee et al., 2006). It is interesting to note that under low $\mathrm{Cu}$ availability, intracellular $\mathrm{Cu}$ distribution is performed by metallochaperones, which are soluble Cu-binding proteins (for a specific review see Huffman and O'Halloran, 2000; Puig and Thiele, 2002).

A further aspect that could be of interest in relation to the plant responses to the excess of $\mathrm{Cu}$ is its interaction with other nutrients/ elements, which may involve complex responses at the metabolic level. In this respect, it has been demonstrated that acquisition of Fe in maize (Astolfi et al., 2003), barley (Astolfi et al., 2006), tomato (Zuchi et al., 2009) and wheat (Zuchi et al., 2012) plants, and of nitrate in spinach and cucumber plants (Nikolic et al., 2007; Prosser et al., 2001) as well as the response to Cd toxicity in barley (Astolfi et al., 2012) are all linked to sulfur (S) availability. In fact, plants produce a large amount of thiols (mainly glutathione) to overcome oxidative stress (Del Buono et al., 2011; Foyer and Noctor, 2011) and for synthesis of metal-binding S compounds (Shahbaz et al., 2010), thus also the exposure to $\mathrm{Cu}$ toxicity could result in higher $\mathrm{S}$ nutritional requirement in these plants. As a consequence, an inadequate $S$ availability could impair the plant capability not only to cope with the excess of $\mathrm{Cu}$, but also to acquire other nutrients. This aspect is even more serious considering that, over recent years, the decrease of atmospheric $\mathrm{SO}_{2}$ emissions and lower $\mathrm{S}$ supply through mineral fertilization have caused an increased occurrence of $\mathrm{S}$ deficiency in many agricultural soils, with physiological responses of plants to S deficiency (McGrath and Zhao, 1995; McGrath et al., 2002). In addition, this picture is further complicated by the fact that also herbicide detoxification requires $S$, being the conjugating of these chemicals with glutathione one of the main steps for the detoxification of the herbicide itself (Del Buono and Ioli, 2011). Moreover, it has been also shown that herbicides can have negative effects on Fe-acquisition processes exacerbating the problems of $\mathrm{Fe}$ deficiency (for more details see Del Buono et al., 2015; Mimmo et al., 2014). All these evidences taken together suggest that the crop response to $\mathrm{Cu}$ toxicity, at least for the large request of $\mathrm{S}$ needed for coping with the stress, can interfere both with the acquisition processes of nutrients (with deleterious impacts for yield and quality) and the crop capacity to detoxify herbicides, which are commonly used to optimize crop productivity.

With respect to soil microorganisms, it is well demonstrated that heavy metal ions, when present above a given threshold level, can form non specific complexes within the cells thereby exerting toxic effects (Dupont et al., 2011). In both Escherichia coli and Bacillus subtilis, the excess of $\mathrm{Cu}$ has been shown to cause an increased uptake of $\mathrm{Fe}$ and $\mathrm{S}$ due to a decreased stability of $\mathrm{Fe}-\mathrm{S}$ clusters during biogenesis or when bound to their target proteins (Chillappagari et al., 2010; Macomber and Imlay, 2009). For instance, several enzymes containing $\mathrm{Fe}-\mathrm{S}$ clusters involved in the biosynthesis of branched amino acids, in the cycle of tricarboxylic acids and in the pentose phosphate pathway resulted strongly impaired in their functionality by high levels of $\mathrm{Cu}$ in both $\mathrm{E}$. coli and B. subtilis (Macomber and Imlay, 2009). Since these enzymes play pivotal roles in the cell metabolism, $\mathrm{Cu}$ concentration in the cytosol is kept to minimum values through the activity of (Cuextruding) P-type ATPase which allows only extremely low concentrations of free $\mathrm{Cu}$ within the cells (Changela et al., 2003). In aerobic conditions, $\mathrm{Cu}$ catalyzes reactions that result in the production of hydroxyl radicals through the Fenton and Haber-Weiss reactions (Halliwell and Gutteridge, 1984). These highly reactive ROS thereby formed are responsible for lipid peroxidation, oxidation of proteins and damage to nucleic acids (Halliwell and Gutteridge, 1990; Stadtman, 1992). The majority of bacteria circumvent these issues by targeting $\mathrm{Cu}$-containing enzymes towards the periplasm or exposing them onto the outer face of the plasma membrane (Dupont et al., 2011), thus adopting an exclusion mechanism.

Taken together, these pieces of evidence point out that the presence of high $\mathrm{Cu}$ availability can consistently affect soil microbial population having then, as a consequence, also an impact in the soil biogeochemical cycles of the other essential elements (Mackie et al., 2013). 


\section{Agronomic practices impacting the rhizosphere and aimed at limiting Cu toxicity}

It is evident that, for fields where anthropic events have caused $\mathrm{Cu}$ accumulation in the upper layers, the most appropriate agronomic practices in the short-and long-term are those based on protecting plants against pathogens using possible alternative approaches to those Cu-based and/or limiting the distribution in soils of $\mathrm{Cu}$-containing amendments/products. In this way, it will be reduced to limit the continuous supply of $\mathrm{Cu}$ to soil. However, where the problem of $\mathrm{Cu}$ toxicity is already present and must be faced anyhow, the only alternative available for farmers in order to ensure crop yield, otherwise diminishing considerably and worsening in its quality (Cambrollé et al., 2015; Juang et al., 2014; Tanyolaç et al., 2007; Toselli et al., 2009), is the application of agricultural practices aimed at restricting the plant-available $\mathrm{Cu}$ fractions in the soil. To this purpose, it is possible to use organic and inorganic compounds, such as limestone, phosphates, clays, zeolites, Fe oxides, OM, and biochar (Ambrosini et al., 2015a; Arunakumara et al., 2013; Kumpiene et al., 2008; Terzano et al., 2005b). Their use is based on the capability to induce various sorption processes (adsorption to mineral surfaces, formation of stable complexes with organic ligands, surface precipitation, and ion exchange) limiting the $\mathrm{Cu}$ bioavailability. Precipitation as salts and co-precipitation can also contribute to reducing contaminant mobility. $\mathrm{Cu}$ leaching can be a further problem of these soils and, for this reason, it should be limited or avoided. In general, soil amendments (as adding OM, lime, phosphates, etc.) are not a novelty, and they have been used for many years both to limit the $\mathrm{Cu}$ phytotoxicity and to improve crop growth and yield (Bolan et al., 2001). In the following chapters, lime and OM applications are discussed in relation to the most recent literature. In addition, the possibility to inoculate crops with arbuscular mycorrhizal fungi (AMF) and bacteria strains, to adopt different systems of cultivation and plans of fertilization, are also discussed. Advantages and disadvantages of the different agricultural practices discussed are also summarized in Table 2.

\subsection{Lime application to soil}

This practice, promoting the alkalinization of soil solution and, thus, inducing the de-protonation of acidic functional groups on the surface of soil particles, increases the soil cation exchange capacity (CEC) and, concurrently, enhances the adsorption of $\mathrm{Cu}$ (Joris et al., 2012). In addition, the $\mathrm{CO}_{3}^{2-}$ and $\mathrm{OH}^{-}$species, derived from limestone solubilization, can react with $\mathrm{Cu}$ forming $\mathrm{Cu}$-hydroxides and/or Cu-carbonates, which subsequently precipitate. So, by means of these two phenomena, it is possible to achieve a significant decrease of the free-Cu activity in soil solution. A further advantage of soil lime application is the increase of $\mathrm{Ca}$ and $\mathrm{Mg}$ in the soil. While at the root level the increase of Ca limits the anatomy changes caused by $\mathrm{Cu}$ (Chen et al., 2013), the enhanced content of $\mathrm{Mg}$ in shoots guarantees the maintenance of the photosynthetic activity by limiting the replacement of $\mathrm{Mg}$ in chlorophyll molecules by Cu (Yruela, 2009). Moreover, both cations, favouring a sitespecific competition for ions, could prevent the $\mathrm{Cu}$ excess within cell (Arunakumara et al., 2013). Generally, the lime application to acidic soils, through alkalinization, can increase phosphorus availability for plants. In this case, the interaction of $\mathrm{Cu}$ with phosphorous can reduce the mobility of the metal and then $\mathrm{Cu}$ availability for roots. However, it is important to note that liming should be used carefully for its effect on soil pH: in fact, Cu mobility is actually the lowest at slightly alkaline $\mathrm{pH}$ but, due to the formation of $\mathrm{OH}^{-}$ complexes, it could definitely be higher at more alkaline conditions (>10) (van der Sloot et al., 1997). In this respect, an increased Cu mobility may represent a risk for the environment due to the possibility of $\mathrm{Cu}$ leaching along the soil profile. It is interesting to note that by-products like dolomitic residue and, to a lesser extent, gypsum and phosphogypsum are valid alternatives for limiting the mobility and availability of $\mathrm{Cu}$ in soil (Garrido et al., 2005). In general, lime and organic amendments (described in the following chapter), are the most used to decrease $\mathrm{Cu}$ availability in agricultural soils (Pietrzak and Uren, 2011).

\subsection{Organic matter (OM), biochar and coal fly ash applications}

It is well demonstrated that the mobility and availability of $\mathrm{Cu}$ can be consistently limited by OM applications (Bes and Mench, 2008; Shaheen et al., 2015), mainly for the high affinity for $\mathrm{Cu}$ of its carboxilic functional groups (see Section Soil $\mathrm{Cu}$ forms and their biogeochemical cycles). However, for the coexistence in OM of compounds with different molecular weight and water solubility, there may be two distinct phenomena: 1 ) high molecular weight and insoluble fractions of $\mathrm{OM}$ can retain significant concentrations of $\mathrm{Cu}$, restricting the fraction of $\mathrm{Cu}$ in soil solution (Chirenje and $\mathrm{Ma}$, 1999); 2) in the presence of low molecular weight and soluble compounds (dissolved $\mathrm{OM}$ ), the $\mathrm{Cu}$ complexes formed could maintain the solubility. In this latter case, the Cu mobility could also increase (Hsu and Lo, 2000) favouring leaching of the metal. In this respect, Ruttens et al. (2006) showed that Cu leaching can increase up to 30 times as a consequence of organic compost application. These evidences highlight that, in the management of this agronomic practice, particular attention should be paid in order to not transform a potential risk ( $\mathrm{Cu}$ not soluble and not mobile) in a real risk ( $\mathrm{Cu}$ with higher mobility), thus deteriorating the already altered soil conditions. In this respect, an advantage could derive from the utilization of biochar, which has been considered for heavy metals immobilization via complexing on its surfaces (Beesley et al., 2011). Uchimiya et al. (2011) showed that CEC was the primary mechanism by which biochar enhanced $\mathrm{Cu}$ retention, whereas in a clay-rich, alkaline soil with higher intrinsic $\mathrm{Cu}$ retention capability, the sorption to mineral (ash) components of the char assisted the retention (precipitation). A further efficient tool for controlling Cu mobility is the application of treated coal fly ash to soil with the formation of zeolites or aluminosilicate geopolymers (Terzano et al., 2005a). Mixing sources of OM with fly ash can be of benefit for offsetting a decrease in soil pH due to the decomposition of OM (Jackson and Miller, 2000). The application of fly ash-stabilized sewage sludge also reduced $\mathrm{Cu}$ leaching and availability to crops (Su and Wong, 2004). To this purpose, byproducts like sugar foam can also be used (Garrido et al., 2005).

\subsection{AMF inoculation}

The mutualistic association between arbuscular mycorrhizal fungi (AMF) and plant roots can also be a way of minimizing the toxic effects of $\mathrm{Cu}$ in plants grown in soil contaminated with this metal. For example, in vineyards with a long-term foliar application of Cu-based fungicides, some AMF species, in order to ensure their own survival and also of associated plants, have developed strategies to tolerate high $\mathrm{Cu}$ contents in the soil, such as the release of organic substances (e.g. glomalin), which may form complexes with $\mathrm{Cu}$, thus restricting its bioavailability (Ambrosini et al., 2015b; Bedini et al., 2010). Additionally, AMF can store $\mathrm{Cu}$ in cellular compartments such as vesicles and spores, where the metabolic rate is reduced; in this way the toxic effects on plant metabolism can be reduced with benefits for the plant growth and hence for themselves (Cornejo et al., 2013). Generally, the colonization of the root cortex of higher plants by AMF provides an increased interface between roots and soil, functioning as an exchange site of nutrients 
Table 2

Advantages and disadvantages of agronomic practices in reducing Cu toxicity to crops.

\begin{tabular}{|c|c|c|}
\hline $\begin{array}{l}\text { Agronomic } \\
\text { practice }\end{array}$ & Advantages & Disadvantages \\
\hline Liming & $\begin{array}{l}\text { Enhanced } \mathrm{Cu} \text { sorption on soil } \\
\text { Fast } \mathrm{Cu} \text {-precipitates formation } \\
\text { Increased concentrations of } \mathrm{Ca} \text { and } \mathrm{Mg} \text { in soil } \\
\text { Increased } \mathrm{P} \text { availability } \\
\text { Cheap and easy application }\end{array}$ & $\begin{array}{l}\text { At higher } \mathrm{pH} \text {, increased mobilization of } \mathrm{Cu} \text { through formation of soluble complexes } \\
\text { with dissolved organic matter (DOM) and } \mathrm{OH}^{-}\end{array}$ \\
\hline $\begin{array}{l}\text { Organic matter } \\
\qquad(\mathrm{OM}) \text { addition }\end{array}$ & $\begin{array}{l}\text { Formation of strong complexes with high molecular weight } \\
\text { insoluble organic molecules } \\
\text { Organic matter from waste composting can be used } \\
\text { Cheap and easy application }\end{array}$ & $\begin{array}{l}\text { In the presence of DOM, soluble Cu complexes may form } \\
\text { Long term stabilization is limited by OM turnover }\end{array}$ \\
\hline Biochar & $\begin{array}{l}\text { Cu sorption on biochar especially through cation exchange } \\
\text { reactions } \\
\text { Increased soil fertility } \\
\text { Cheap amendment also solving problems related to its disposal }\end{array}$ & $\begin{array}{l}\text { Reduced effectiveness of herbicides } \\
\text { Potential introduction of other contaminants } \\
\text { Potential negative impact on soil bacteria and fauna } \\
\text { Long term stabilization is limited by OM turnover }\end{array}$ \\
\hline Coal fly ash & $\begin{array}{l}\text { Fast soil alkalinization and Cu sorption on aluminosilicate } \\
\text { phases } \\
\text { Cheap amendment also solving problems related to coal fly ash } \\
\text { disposal }\end{array}$ & Mobilization of other potentially toxic elements incorporated in coal fly ash \\
\hline Clays and zeolites & $\begin{array}{l}\text { Cu stabilization on the mineral surfaces mainly by cation } \\
\text { exchange processes } \\
\text { Improvement of soil properties related to soil fertility (CEC, } \\
\text { water retention, etc.) } \\
\text { Easy application }\end{array}$ & $\begin{array}{l}\text { Problems related to the exploitation of mineral natural resources. For zeolites, synthetic } \\
\text { minerals can be easily synthesized from waste materials } \\
\text { Remobilization of } \mathrm{Cu} \text { if other cations displace it from exchange sites }\end{array}$ \\
\hline $\begin{array}{l}\text { Arbuscular } \\
\text { Mycorrhizal } \\
\text { Fungi }\end{array}$ & $\begin{array}{l}\text { Release of organic substances which may form complexes with } \\
\mathrm{Cu} \\
\mathrm{Cu} \text { cellular compartmentalization in vesicles and spores of } \\
\mathrm{AMF} \\
\text { Increased interface between roots and soil, facilitating nutrient } \\
\text { uptake }\end{array}$ & $\mathrm{Cu}$ uptake can be increased as well by the increased root biomass \\
\hline $\begin{array}{l}\text { Bacteria } \\
\quad \text { inoculation }\end{array}$ & $\begin{array}{l}\text { Bacterial detoxification of } \mathrm{Cu} \text { through hyperaccumulation or } \\
\text { release of strong metal chelating molecules } \\
\text { Reduction of metal uptake by plants } \\
\text { Reduction of ethylene-dependent detrimental stress }\end{array}$ & Competition with plants for water and nutrients \\
\hline Intercropping & $\begin{array}{l}\mathrm{Cu} \text { immobilization in the root apoplast of grasses } \\
\mathrm{Cu} \text { uptake and accumulation in grasses } \\
\mathrm{Cu} \text { phytostabilization by release of } \mathrm{Cu} \text {-complexing exudates } \\
\text { Easy application }\end{array}$ & $\begin{array}{l}\text { Competition with crops for water and nutrients } \\
\text { Higher supply of } \mathrm{N} \text { needed }\end{array}$ \\
\hline $\mathrm{N}$ fertilization & $\begin{array}{l}\mathrm{NO}_{3}^{-} \text {application favors soil alkalinization around roots thus } \\
\text { reducing } \mathrm{Cu} \text { availability }\end{array}$ & $\begin{array}{l}\mathrm{NH}_{4}^{+} \text {application causes acidification of the rhizosphere thus increasing } \mathrm{Cu} \text { availability } \\
\text { Costly }\end{array}$ \\
\hline Fe fertilization & $\begin{array}{l}\text { Adequate Fe supply reduces rhizosphere acidification by roots } \\
\text { thus limiting } \mathrm{Cu} \text { availability }\end{array}$ & $\begin{array}{l}\text { High Fe concentrations can displace } \mathrm{Cu} \text { from organic complexes thus increasing } \mathrm{Cu} \\
\text { availability } \\
\text { Costly }\end{array}$ \\
\hline S fertilization & $\begin{array}{l}\text { Increased Fe and } \mathrm{N} \text { assimilation } \\
\text { Increased capacity to respond to Cu stress, and to detoxify } \\
\text { herbicides and xenobiotics }\end{array}$ & Costly \\
\hline
\end{tabular}

between the plant and AMF. Thus, nutrients with low mobility in soil, such as P, can be absorbed by roots in greater quantity with a positive impact in the nutritional status of plants (Ambrosini et al., 2015b). The positive advantages of this root colonization support the hypothesis of its potential exploitation at the field level as a promising agricultural practice to guarantee crop yield.

\subsection{Bacteria inoculation}

Beside AMF, also bacteria can be used for the limitation of $\mathrm{Cu}-$ induced toxicity. In general, the mechanisms used by microorganisms to detoxify heavy metals include the active transport (through the activity of efflux pumps), intra- and extracellular sequestration and transformation to other less toxic compounds via enzymatic reactions (Colin et al., 2012). Studies have indicated that the interactions between bacteria and plant roots can greatly enhance the ability of plants to take up metals (Dary et al., 2010; Glick, 2010; He et al., 2010, 2009). Elsholtzia splendens inoculated with the bacterial strain MS2 had for instance significantly greater concentrations of $\mathrm{Cu}$ in shoots and roots than un-inoculated plants (Chen et al., 2005). Furthermore, microorganisms can also increase the tolerance of plants to metals, which can occur by a) transformation of the metals into less toxic forms (Carlot et al., 2002), b) reduction of metal uptake by plants (Vivas et al., 2006) and/or c) reduction of ethylene-dependent detrimental stress caused by heavy metals, without affecting their uptake (Rajkumar and Freitas, 2008). For instance, the Cu-resistant actinobacteria Amycolatopsis tucumanensis was able to alleviate $\mathrm{Cu}$ toxicity symptoms in the indicator species Zea mays (Albarracín et al., 2010). Amycolatopsis tucumanensis has been shown to accumulate high amounts of $\mathrm{Cu}$ in a produced exopolymer that is mainly stored within the cell (Albarracín et al., 2008). Such phenotype of Cu-bioaccumulation is related to the expression of a Cu P-Type ATPase, also found in other resistant microorganisms (Solioz and Vulpe, 1996). Similarly, the co-inoculation of Vicia faba grown under Cu-stress with Rhizobium and a mixture of PGPR, namely Enterobacter clocae and Pseudomonas sp. determined an increase in the plant biomass production and a strong reduction in Cu taken up by plants, demonstrating that Cu-accumulating PGPR can alleviate Cu stress (Fatnassi et al., 2015). Nonetheless, besides the ability of several bacterial strains to hyperaccumulate and/or sequestrate $\mathrm{Cu}$, many microorganisms inhabiting the rhizosphere might release metal-chelating molecules, such as siderophores (MS), in the close proximity of the root (Dimkpa et al., 2009). These MS can, on one hand, influence the plant 
uptake of various metals, as for instance $\mathrm{Fe}, \mathrm{Zn}$ and $\mathrm{Cu}$ (CarrilloCastañeda et al., 2002, 2005; Egamberdiyeva, 2007) whilst, on the other hand, they can most likely chelate and reduce the toxic metal concentration in the rhizosphere, exerting a bioprotection effect. Indeed, the ability of some bacteria to protect plants against either $\mathrm{Ni}, \mathrm{Pb}$ or $\mathrm{Zn}$ toxicity has previously been shown related to the production of MS (Burd et al., 2000; Dimkpa et al., 2008).

In addition, the majority of the environmental stresses result in the production of inhibitory levels of "stress ethylene" in plants (Abeles et al., 1992). Several PGPR can express the enzyme 1aminocyclopropane-1-carboxylate (ACC) deaminase (Blaha et al., 2006; Glick et al., 2007; Honma and Shimomura, 1978), which interferes with the biosynthesis of ethylene. In this way, PGPR can prevent plant ethylene levels from becoming growth inhibitory (Burd et al., 1998; Glick, 1995). Several examples of bacteria ameliorating heavy metal stress in plants by using this strategy have already been reported for Ni, Cd and Cu (Burd et al., 2000, 1998; Cheng et al., 2009; Nie et al., 2002; Reed and Glick, 2005; Reed et al., 2005; Safronova et al., 2006).

Also in this case there are positive experiences supporting the idea that bacterial inoculation could be a promising strategy to cope with the excess of $\mathrm{Cu}$ in the soil.

\subsection{Intercropping strategy}

It has been clearly demonstrated in Fe-deficiency that dicots, as for instance citrus and peanut plants, when intercropped with cover crops, can benefit of the PS released by the roots of grasses with an improvement in the acquisition of Fe (Cesco et al., 2006; Xiong et al., 2013). In this regard, it is interesting the finding made in large areas of Brazil where vine plants were co-cultivated with grasses. The main reason of this choice was related to the soil conservation and/or protection from erosion. However, in this particular crop system vine plants, when grown in $\mathrm{Cu}-$ contaminated soils, do not exhibit any symptoms at lower concentrations (Miotto et al., 2013). This evidence seems to indicate that also in this case, where Cu toxicity is the critical point, a beneficial interaction in the intermingling root occurred. At the moment the phenomenon is still not clarified, however it could be hypothesized that the contemporary presence in the same volume of soil (rhizosphere) of grasses roots and those of the other crop species (in this specific case vine plants) could reduce the magnitude of the available fraction of $\mathrm{Cu}$ via different mechanisms as i) immobilization of $\mathrm{Cu}$ in the root apoplast of grasses, ii) competition in its uptake (Terzano et al., 2014) and accumulation and compartmentalization of the metal at the shoot level, iii) phytostabilization as a consequence of the release of $\mathrm{Cu}$-complexing exudates. A deeper understanding of this phenomenon is a prerequisite for a better exploitation of the potential aspects and advantages of this practice. In this regard, it should be noted that the co-presence of two plant species in the same field, while on one side allows to limit the impact of excess $\mathrm{Cu}$ (although via processes yet to be clarified), on the other side this cropping system requires higher availability of water and nutrients to limit the onset of nutrient competitions between the two plant species. This aspect is of considerable relevance in particular in relation to the nitrogen nutrition and the role of amino acid metabolism in the levels of aromas in fruits (Ojeda-Real et al., 2009; Parisi et al., 2006), aspect of paramount importance for example for the grapevine (Bell et al., 1979; Ough and Bell, 1980). Moreover, an adequate supply of nitrogen is essential also for grasses in order to ensure an adequate production and release of PS (and organic acids) in the rhizosphere (Aciksoz et al., 2011), prerequisite to restrict the fraction of available $\mathrm{Cu}$ in soil solution and to make this crop practice really effective for the purpose.
In this regard, also the use of transgenic plants able to extract and accumulate high amounts of $\mathrm{Cu}$ from soil could be foreseen. Several pieces of research have been focused on the phytoextraction of metals, $\mathrm{Cu}$ included (Cherian and Oliveira, 2005; Eapen and D'Souza, 2005; Kotrba et al., 2009; Krämer and Chardonnens, 2001; Papoyan and Kochian, 2004), demonstrating that the cloning and the overexpression of the gene encoding for the glutathione synthetase in Brassica juncea determined both a higher tolerance and a higher accumulation of $\mathrm{Cd}, \mathrm{Zn}, \mathrm{Cr}, \mathrm{Cu}$ and $\mathrm{Pb}$ in this specie (Bennett et al., 2003; Zhu et al., 1999). However, despite these very promising results, reports about field trials involving transgenic hyperaccumulating plants are still missing. Moreover, the impact of these genetically modified plants in the environment is still matter of debate limiting their application in a real productive context in several countries.

\subsection{Fertilization}

Fertilization is a very old practice aimed at maintaining the adequate levels of soil fertility at the beginning of a new crop cycle and specifically at satisfying the needs of the just-planted crop. Moreover, with respect to the nutrients considered in the classic plans of fertilizations, farmers have the possibility to use, for the same nutrient, different forms and sources. This is an important aspect also in relation to the excess of $\mathrm{Cu}$; in fact, different sources/ forms of fertilizers can have a totally different impact in the rhizosphere and, then, with respect to $\mathrm{Cu}$, in its levels of toxicity. An example can be nitrogen fertilization: when planned with $\mathrm{NO}_{3}^{-}$, an alkalinization of the soil surrounding the roots occurs as a consequence of the nitrate acquisition by roots (Britto and Kronzucker, 2013); this effect can limit the availability of $\mathrm{Cu}$. This aspect is particularly relevant in the case of acidic soils. In fact, high concentrations of protons can prevent acidic functional groups of organic acids from dissociation and thus from complexing $\mathrm{Cu}$, thereby reducing their ability to alleviate $\mathrm{Cu}$ toxicity in plants. For this reason, also the $\mathrm{N}$-fertilization with ammonium, which uptake induces the acidification of the rhizosphere, might exacerbate $\mathrm{Cu}$ toxicity.

A further relevant aspect is the nutritional status of crops. In fact, it is well known that Fe deficiency induces in several dicots (like also rootstocks of grafted vine plants) an intense acidification of the rhizosphere (Brancadoro et al., 1995); this action is ascribed to the roots effort to mobilize the nutrient from its barely available forms in the soil (Marschner, 2011). This phenomenon occurs often in calcareous soils where the availability of Fe could be consistently limited (Mimmo et al., 2014). It is clear that, if this nutritional disorder (Fe deficiency) occurred also in soils contaminated by $\mathrm{Cu}$, this acidification would also increase $\mathrm{Cu}$ availability. For this reason, the maintenance of an adequate Fe availability, also through targeted fertilizations, could be a valid strategy both to limit the onset of Fe deficiency and, concomitantly, to prevent $\mathrm{Cu}$ toxicity for crops. On the other hand, this practice should be used carefully in order to avoid an excessive availability of Fe. In fact, organic acids display a higher affinity for Fe than $\mathrm{Cu}$; therefore, in the presence of high $\mathrm{Fe}$ concentrations, metal exchange reactions can occur (Fe vs. $\mathrm{Cu}$ ) thus limiting the effectiveness of these compounds in contrasting $\mathrm{Cu}$ toxicity.

The interactions between mechanisms underlying, at the root level, the acquisition of nutrients could be even more relevant in relation to the definition of agronomical practices aimed at coping with the $\mathrm{Cu}$ toxicity. In fact, as stated before, it has been clearly demonstrated that $\mathrm{S}$ deficiency can limit the capability of plants to acquire Fe in maize (Astolfi et al., 2003; Bouranis et al., 2003), barley (Astolfi et al., 2006; Kuwajima and Kawai, 1997), tomato (Zuchi et al., 2009) and durum wheat (Zuchi et al., 2012). In these 
studies it has been suggested that in grasses ("Strategy II" plants) this effect could be ascribed to a decrease in the production and release of PS induced by S deficiency, whereas in tomato (a "Strategy I" plant) the effect was rather due to a reduced nicotianamine and ethylene production, which could impair both the activity of the Ferric chelate reductase and the capacity of the $\mathrm{Fe}$ transporter IRT1 to mediate the Fe ${ }^{\text {II }}$ flux across the plasma membrane. It has been also demonstrated that the acquisition of nitrate and its assimilative metabolism is impaired by inadequate availability of S (Iacuzzo et al., 2011; Nikolic et al., 2007; Prosser et al., 2001). These aspects are of relevance in relation to Cu toxicity; in fact, an effective response to the oxidative stress (Del Buono et al., 2011; Foyer and Noctor, 2011), as also induced by Cu excess, as well as an efficient detoxification from xenobiotics like herbicides (Del Buono and Ioli, 2011), strictly depend on an adequate availability of S. Considering that agricultural soils are becoming depleted in S (McGrath et al., 2002), the strategy to ensure a stable input of this nutrient via specific plans of fertilization could ensure both the efficiency of the processes for the acquisition and assimilation of other nutrients and an effective capacity to cope with the stress induced by an excess of $\mathrm{Cu}$, as suggested for example for the management of $\mathrm{Cu}$ contaminated paddy soils (Sun et al., 2016).

These evidences taken together highlight the need of practices to deal with $\mathrm{Cu}$ toxicity. It is therefore presumable that the simultaneous use of more than one practice at a time may allow dealing more effectively these critical issues.

\section{Conclusions and future perspectives}

Considered that limiting the $\mathrm{Cu}$ distribution in the field is a priority to face the problem of the progressive $\mathrm{Cu}$ accumulation in the soils, there is no doubt that for those soils where the $\mathrm{Cu}$ accumulation and toxicity are already present thus limiting agricultural production, it is essential to define appropriate strategies aimed at restoring the fertility and future usability of these soils.

Some strategies are already available and frequently utilized (e.g. lime and OM applications). Some of the mechanisms underlying these strategies are already known; however, there are processes, in particular those occurring at the rhizosphere level, still not totally clarified. Only their comprehension can guarantee a better exploitation of these practices at field conditions. For other strategies (e.g. intercropping, fertilization with interactions among nutrients, etc.), experience and knowledge are either still scarce at the field scale or, on the contrary, yet only limited at field observations. It is clear that their effective exploitation requires a wider understanding of the processes and mechanisms occurring at the rhizosphere, as in the case of dicot/grass intercropping. In fact, through the awareness of what is occurring in the rhizosphere of these soils (i.e. soil processes of elements/nutrients solubilization/ mobilization, mechanisms of nutrients acquisition and allocation, release of exudates, competitions/interactions between nutrients, root/bacterium/fungus interaction), it is possible to define the applicability details of agricultural practices able to both a) cope with the problem of guarantying the yield and b) avoid environmental worsening, as it might occur through an uncontrolled mobilization of $\mathrm{Cu}$ accumulated in the soil with its leaching along the profile. Facing these challenges is even more relevant considering that the food production to fulfil the demand of the progressively increasing world population will need a deeper exploitation of all agricultural surfaces, including the contaminated ones.

\section{Acknowledgments}

This research was supported by grants from Italian MIUR (FIRB -
Programma 'Futuro in Ricerca' 2012), the Free University of Bolzano (TN5056, TN2053). We are grateful to Fundação de Amparo à Pesquisa do Estado do Rio Grande do Sul (Foundation for Research Support of the State of Rio Grande do Sul) - FAPERGS (process number 1971-2551/13-2) and the Conselho Nacional de Desenvolvimento Científico e Tecnológico (Brazilian National Council for Scientific and Technological Development) - CNPq (process number 473376/2013-0). The first author thank the CNPq for research grant. All authors contributed equally to this work.

\section{References}

Abeles, F.B., Morgan, P.W., Saltveit Jr., M.E., 1992. Ethylene in Plant Biology. Academic Press, New York. http://dx.doi.org/10.1016/B978-0-08-091628-6.50016-3.

Aciksoz, S.B., Ozturk, L., Gokmen, O.O., Römheld, V., Cakmak, I., 2011. Effect of nitrogen on root release of phytosiderophores and root uptake of $\mathrm{Fe}$ (III)phytosiderophore in Fe-deficient wheat plants. Physiol. Plant 142, 287-296. http://dx.doi.org/10.1111/j.1399-3054.2011.01460.x.

Ahonen-Jonnarth, U., Van Hees, P.A.W., Lundstrom, U.S., Finlay, R.D., 2000. Organic acids produced by mycorrhizal Pinus sylvestris exposed to elevated aluminium and heavy metal concentrations. New Phytol. 146, 557-567. http://dx.doi.org/ 10.1046/j.1469-8137.2000.00653.x.

Alaoui-Sossé, B., Genet, P., Vinit-Dunand, F., Toussaint, M.-L., Epron, D., Badot, P.-M., 2004. Effect of copper on growth in cucumber plants (Cucumis sativus) and its relationships with carbohydrate accumulation and changes in ion contents. Plant Sci. 166, 1213-1218. http://dx.doi.org/10.1016/j.plantsci.2003.12.032.

Albarracín, V.H., Amoroso, M.J., Abate, C.M., 2010. Bioaugmentation of copper polluted soil microcosms with Amycolatopsis tucumanensis to diminish phytoavailable copper for Zea mays plants. Chemosphere 79, 131-137. http:// dx.doi.org/10.1016/j.chemosphere.2010.01.038.

Albarracín, V.H., Winik, B., Kothe, E., Amoroso, M.J., Abate, C.M., 2008. Copper bioaccumulation by the actinobacterium Amycolatopsis sp. AB0. J. Basic Microbiol 48, 323-330. http://dx.doi.org/10.1002/jobm.200700360.

Alleoni, L.R.F., Borba, R.P., de CAcamargo, O.A., 2005. Metais pesados: da cosmogênese aos solos brasileiros. Tópicos em ciência do solo 4, 1-42.

Alloway, B., 1995. Heavy Metals in Soils. Chapman \& Hall, London.

Ambrosini, V.G., Rosa, D.J., Corredor Prado, J.P., Borghezan, M., Bastos de Melo, G.W., Fonsêca de Sousa Soares, C.R., Comin, J.J., Simão, D.G., Brunetto, G., 2015a. Reduction of copper phytotoxicity by liming: a study of the root anatomy of young vines (Vitis labrusca L.). Plant Physiol. Biochem. 96, 270-280. http:// dx.doi.org/10.1016/j.plaphy.2015.08.012.

Ambrosini, V.G., Voges, J.G., Canton, L., Couto, R., da, R., Ferreira, P.A.A., Comin, J.J., Melo, G.W.B. de, Brunetto, G. Soares, C.R.F.S., 2015b. Effect of arbuscular mycorrhizal fungi on young vines in copper-contaminated soil. Braz. J. Microbiol.

Apel, K., Hirt, H., 2004. Reactive oxygen species: metabolism, oxidative stress, and signal transduction. Annu. Rev. Plant Biol. 55, 373-399. http://dx.doi.org/ 10.1146/annurev.arplant.55.031903.141701.

Arunakumara, K.K.I.U., Walpola, B.C., Yoon, M.-H., 2013. Aluminum toxicity and tolerance mechanism in cereals and legumes - A review. J. Korean Soc. Appl. Biol. Chem. 56, 1-9. http://dx.doi.org/10.1007/s13765-012-2314-z.

Astolfi, S., Cesco, S., Zuchi, S., Neumann, G., Roemheld, V., 2006. Sulfur starvation reduces phytosiderophores release by iron-deficient barley plants. Soil Sci. Plant Nutr. 52, 43-48. http://dx.doi.org/10.1111/j.1747-0765.2006.00010.x.

Astolfi, S., Zuchi, S., Neumann, G., Cesco, S., Di Toppi, L.S., Pinton, R., 2012. Response of barley plants to Fe deficiency and Cd contamination as affected by S starvation. J. Exp. Bot. 63, 1241-1250. http://dx.doi.org/10.1093/jxb/err344.

Astolfi, S., Zuchi, S., Passera, C., Cesco, S., 2003. Does the sulfur assimilation pathway play a role in the response to Fe deficiency in maize (Zea mays L.) plants. J. Plant Nutr. 26, 2111-2121. http://dx.doi.org/10.1081/PLN-120024268.

Badalucco, L., Nannipieri, P., 2007. Nutrient transformations in the rhizosphere. In: Pinton, R., Varanini, Z., Nannipieri, P. (Eds.), The Rhizosphere. Biochemistry and Organic Substances at the Soil-plant Interface. CRC Press, Taylor and Francis Group, Boca Raton, FL, pp. 111-133.

Bedini, S., Turrini, A., Rigo, C., Argese, E., Giovannetti, M., 2010. Molecular characterization and glomalin production of arbuscular mycorrhizal fungi colonizing a heavy metal polluted ash disposal island, downtown Venice. Soil Biol. Biochem. 42, 758-765. http://dx.doi.org/10.1016/j.soilbio.2010.01.010.

Beesley, L., Moreno-Jiménez, E., Gomez-Eyles, J.L., Harris, E., Robinson, B., Sizmur, T., 2011. A review of biochars' potential role in the remediation, revegetation and restoration of contaminated soils. Environ. Pollut. 159, 3269-3282. http:// dx.doi.org/10.1016/j.envpol.2011.07.023.

Bell, A.A., Ough, C.S., Kliewer, W.M., 1979. Effects on must and wine composition, rates of fermentation, and wine quality of nitrogen fertilization of Vitis Vinifera Var. Thompson Seedless grapevines. Am. J. Enol. Vitic. 30, 124-129.

Bellaloui, N., Reddy, K.N., Zablotowicz, R.M., Abbas, H.K., Abel, C.A., 2009. Effects of glyphosate application on seed iron and root ferric (III) reductase in soybean cultivars. J. Agric. Food Chem. 57, 9569-9574. http://dx.doi.org/10.1021/ jf902175y.

Bennett, L.E., Burkhead, J.L., Hale, K.L., Terry, N., Pilon, M., Pilon-Smits, E.A.H., 2003. Analysis of transgenic Indian mustard plants for phytoremediation of metal- 
contaminated mine tailings. J. Environ. Qual. 32, 432-440.

Bes, C., Mench, M., 2008. Remediation of copper-contaminated topsoils from a wood treatment facility using in situ stabilisation. Environ. Pollut. 156, 1128-1138. http://dx.doi.org/10.1016/j.envpol.2008.04.006.

Blaha, D., Prigent-Combaret, C., Mirza, M.S., Moënne-Loccoz, Y., 2006. Phylogeny of the 1-aminocyclopropane-1-carboxylic acid deaminase-encoding gene acdS in phytobeneficial and pathogenic Proteobacteria and relation with strain biogeography. FEMS Microbiol. Ecol. 56, 455-470.

Bolan, N.S., Adriano, D.C., Curtin, D., 2001. Soil acidification and liming interactions with nutrientand heavy metal transformationand bioavailability. Adv. Agron. 78, 215-272. http://dx.doi.org/10.1016/S0065-2113(02)78006-1.

Borges, F., Guimarães, C., Lima, J.L.F.C., Pinto, I., Reis, S., 2005. Potentiometric studies on the complexation of copper(II) by phenolic acids as discrete ligand models of humic substances. Talanta 66, 670-673. http://dx.doi.org/10.1016/ j.talanta.2004.12.012.

Bouranis, D.L., Chorianopoulou, S.N., Siyiannis, V.F., Protonotarios, V.E., Hawkesford, M.J., 2003. Aerenchyma formation in roots of maize during sulphate starvation. Planta 217, 382-391. http://dx.doi.org/10.1007/s00425-0031007-6.

Bradl, H.B., 2004. Adsorption of heavy metal ions on soils and soils constituents. J. Colloid Interface Sci. 277, 1-18. http://dx.doi.org/10.1016/j.jcis.2004.04.005.

Brancadoro, L., Rabotti, G., Scienza, A., Zocchi, G., 1995. Mechanisms of Fe-efficiency in roots of Vitis spp. in response to iron deficiency stress. Plant Soil 171, 229-234. http://dx.doi.org/10.1007/BF00010276.

Brimecombe, M., De Lelj, F., Lynch, J., 2001. The effect of root exudates on rhizosphere microbial populations. In: Pinton, R., Varanini, Z.P.N. (Eds.), E Rhizosphere Biochemistry and Organic Substances at the Soil-plant Interface. Marcel Dekker, New York, pp. 94-140.

Britto, D.T., Kronzucker, H.J., 2013. Ecological significance and complexity of Nsource preference in plants. Ann. Bot. 112, 957-963. http://dx.doi.org/10.1093/ aob/mct157.

Brunetto, G., Miotto, A., Ceretta, C.A., Schmitt, D.E., Heinzen, J., de Moraes, M.P., Canton, L., Tiecher, T.L., Comin, J.J., Girotto, E., 2014. Mobility of copper and zinc fractions in fungicide-amended vineyard sandy soils. Arch. Agron. Soil Sci. 60, 609-624. http://dx.doi.org/10.1080/03650340.2013.826348.

Burd, G.I., Dixon, D.G., Glick, B.R., 2000. Plant growth-promoting bacteria that decrease heavy metal toxicity in plants. Can. J. Microbiol. 46, 237-245. http:// dx.doi.org/10.1139/w99-143.

Burd, G.I., Dixon, D.G., Glick, B.R., 1998. A plant growth-promoting bacterium that decreases nickel toxicity in seedlings. Appl. Environ. Microbiol. Environ. 64, 3663-3668.

Cambrollé, J., García, J.L., Figueroa, M.E., Cantos, M., 2015. Evaluating wild grapevine tolerance to copper toxicity. Chemosphere 120, 171-178. http://dx.doi.org/ 10.1016/j.chemosphere.2014.06.044.

Cambrollé, J., García, J.L., Ocete, R., Figueroa, M.E., Cantos, M., 2013. Growth and photosynthetic responses to copper in wild grapevine. Chemosphere 93, 294-301. http://dx.doi.org/10.1016/j.chemosphere.2013.04.080.

Carlot, M., Giacomini, A., Casella, S., 2002. Aspects of plant-microbe interactions in heavy metal polluted soil. Acta Biotechnol. 22,13-20. http://dx.doi.org/10.1002/ 1521-3846(200205)22:1/2<13::AID-ABIO13>3.0.CO;2-9.

Carrillo-Castañeda, G., Muñoz, J.J., Peralta-Videa, J.R., Gomez, E., GardeaTorresdey, J.L., 2005. Modulation of uptake and translocation of Iron and Copper from root to shoot in common bean by siderophore-producing microorganisms. J. Plant Nutr. 28, 1853-1865. http://dx.doi.org/10.1080/01904160500251340.

Carrillo-Castañeda, G., Juárez Muñoz, J., Ramón Peralta-Videa, J., Gomez, E., GardeaTorresdey, J.L., 2002. Plant growth-promoting bacteria promote copper and iron translocation from root to shoot in alfalfa seedlings. J. Plant Nutr. 26, 1801-1814. http://dx.doi.org/10.1081/PLN-120023284.

Cesco, S., Rombolà, A.D., Tagliavini, M., Varanini, Z., Pinton, R., 2006. Phytosiderophores released by graminaceous species promote ${ }^{59} \mathrm{Fe}$-uptake in citrus. Plant Soil 287, 223-233. http://dx.doi.org/10.1007/s11104-006-9069-4.

Chaignon, V., Di Malta, D., Hinsinger, P., 2002. Fe-deficiency increases Cu acquisition by wheat cropped in a Cu-contaminated vineyard soil. New Phytol. 154, 121-130. http://dx.doi.org/10.1046/j.1469-8137.2002.00349.x.

Chaignon, V., Hinsinger, P., 2003. A biotest for evaluating Copper bioavailability to plants in a contaminated soil. J. Environ. Qual. 32 http://dx.doi.org/10.2134/ jeq2003.8240.

Changela, A., Chen, K., Xue, Y., Holschen, J., Outten, C.E., O'Halloran, T.V., Mondragón, A., 2003. Molecular basis of metal-ion selectivity and zeptomolar sensitivity by CueR. Sci. (80-. ) 301, 1383-1387. http://dx.doi.org/10.1126/ science.1085950.

Chen, P.-Y., Lee, Y.-I., Chen, B.-C., Juang, K.-W., 2013. Effects of calcium on rhizotoxicity and the accumulation and translocation of copper by grapevines. Plant Physiol. Biochem. 73, 375-382. http://dx.doi.org/10.1016/j.plaphy.2013.10.016.

Chen, Y.X., Wang, Y.P., Lin, Q., Luo, Y.M., 2005. Effect of copper-tolerant rhizosphere bacteria on mobility of copper in soil and copper accumulation by Elsholtzia splendens. Environ. Int. 31, 861-866. http://dx.doi.org/10.1016/ j.envint.2005.05.044.

Cheng, Z., Wei, Y.-Y., Sung, W., Glick, B., McConkey, B., 2009. Proteomic analysis of the response of the plant growth-promoting bacterium Pseudomonas putida UW4 to nickel stress. Proteome Sci. 7, 18.

Cherian, S., Oliveira, M.M., 2005. Transgenic plants in phytoremediation: recent advances and new possibilities. Environ. Sci. Technol. 39, 9377-9390. http:// dx.doi.org/10.1021/es0511341.

Chillappagari, S., Seubert, A., Trip, H., Kuipers, O.P., Marahiel, M.A., Miethke, M.,
2010. Copper stress affects Iron homeostasis by destabilizing Iron-Sulfur cluster formation in Bacillus subtilis. J. Bacteriol. 192, 2512-2524. http://dx.doi.org/ 10.1128/JB.00058-10.

Chirenje, T., Ma, L.Q., 1999. Effects of acidification on metal mobility in a papermillash amended soil. J. Environ. Qual. 28, 760-767. http://dx.doi.org/10.2134/ jeq1999.00472425002800030005x.

Clemens, S., 2001. Molecular mechanisms of plant metal tolerance and homeostasis. Planta 212, 475-486. http://dx.doi.org/10.1007/s004250000458.

Colin, V.L., Villegas, L.B., Abate, C.M., 2012. Indigenous microorganisms as potential bioremediators for environments contaminated with heavy metals. Int. Biodeterior. Biodegrad. 69, 28-37. http://dx.doi.org/10.1016/j.ibiod.2011.12.001.

Cornejo, P., Pérez-Tienda, J., Meier, S., Valderas, A., Borie, F., Azcón-Aguilar, C. Ferrol, N., 2013. Copper compartmentalization in spores as a survival strategy of arbuscular mycorrhizal fungi in Cu-polluted environments. Soil Biol. Biochem. 57, 925-928. http://dx.doi.org/10.1016/j.soilbio.2012.10.031.

Correia, N.M., Dos Santos, E.A., 2013. Foliar levels of macro and micronutrients in glyphosate-tolerant corn submitted to herbicides. Semin. Agrar. 34, 3165-3171. http://dx.doi.org/10.5433/1679-0359.2013v34n6Supl1p3165.

Couto, R. da R., Ribeiro Lazzari, C.J., Trapp, T., De Conti, L., Comin, J.J., Martins, S.R. Belli Filho, P., Brunetto, G., 2015. Accumulation and distribution of copper and zinc in soils following the application of pig slurry for three to thirty years in a microwatershed of southern Brazil. Arch. Agron. Soil Sci. 1-24. http:// dx.doi.org/10.1080/03650340.2015.1074183.

Covarrubias, J., 2012. Physiological and Biochemical Aspects of Iron Nutrition in Grapevine. University of Bologna.

Dakora, F.D., Phillips, D.A., 2002. Root exudates as mediators of mineral acquisition in low-nutrient environments. Plant Soil 245, 35-47.

Damin, V., Trivelin, P.C.O., Carvalho, S.J.P., Moraes, M.F., Barbosa, T.G., 2010. Herbicide application increases nitrogen $\left({ }^{15} \mathrm{~N}\right)$ exudation and root detachment of Brachiaria decumbens Stapf. Plant Soil 334, 511-519. http://dx.doi.org/10.1007/ s11104-010-0402-6.

Dary, M., Chamber-Pérez, M.A., Palomares, A.J., Pajuelo, E., 2010. “In situ” phytostabilisation of heavy metal polluted soils using Lupinus luteus inoculated with metal resistant plant-growth promoting rhizobacteria. J. Hazard. Mater 177, 323-330. http://dx.doi.org/10.1016/j.jhazmat.2009.12.035.

De Conti, L., Ceretta, C.A., Ferreira, P.A.A., Lourenzi, C.R., Girotto, E., Lorensini, F., Tiecher, T.L., Marchezan, C., Anchieta, M.G., Brunetto, G., 2016. Soil solution concentrations and chemical species of copper and zinc in a soil with a history of pig slurry application and plant cultivation. Agric. Ecosyst. Environ. 216, 374-386. http://dx.doi.org/10.1016/j.agee.2015.09.040.

Del Buono, D., Astolfi, S., Mimmo, T., Bartucca, M.L., Celletti, S., Ciaffi, M., Cesco, S. 2015. Effects of terbuthylazine on phytosiderophores release in iron deficient barley. Environ. Exp. Bot. 116, 32-38. http://dx.doi.org/10.1016 j.envexpbot.2015.03.007.

Del Buono, D., Ioli, G., 2011. Glutathione S-transferases of Italian ryegrass (Lolium multiflorum): activity toward some chemicals, safener modulation and persistence of atrazine and fluorodifen in the shoots. J. Agric. Food Chem. 59, 1324-1329. http://dx.doi.org/10.1021/jf1043713.

Del Buono, D., Ioli, G., Nasini, L., Proietti, P., 2011. A comparative study on the interference of two herbicides in wheat and Italian ryegrass and on their antioxidant activities and detoxification rates. J. Agric. Food Chem. 59, 12109-12115. http://dx.doi.org/10.1021/jf2026555.

Di Donato, R.J., Roberts, L.A., Sanderson, T., Eisley, R.B., Walker, E.L., 2004. Arabidopsis Yellow Stripe-Like2 (YSL2): a metal-regulated gene encoding a plasma membrane transporter of nicotianamine-metal complexes. Plant J. 39, 403-414. http://dx.doi.org/10.1111/j.1365-313X.2004.02128.x.

Dimkpa, C., Svatoš, A., Merten, D., Büchel, G., Kothe, E., 2008. Hydroxamate siderophores produced by Streptomyces acidiscabies E13 bind nickel and promote growth in cowpea (Vigna unguiculata L.) under nickel stress. Can. J. Microbiol. 54, 163-172. http://dx.doi.org/10.1139/W07-130.

Dimkpa, C., Weinand, T., Asch, F., 2009. Plant-rhizobacteria interactions alleviate abiotic stress conditions. Plant. Cell Environ. 32, 1682-1694. http://dx.doi.org/ 10.1111/j.1365-3040.2009.02028.x.

Dong, B., Rengel, Z., Graham, R.D., 1995. Effects of herbicide chlorsulfuron on growth and nutrient uptake parameters of wheat genotypes differing in Zn-efficiency. Plant Soil 173, 275-282. http://dx.doi.org/10.1007/BF00011465.

Dupont, C.L., Grass, G., Rensing, C., 2011. Copper toxicity and the origin of bacterial resistance-new insights and applications. Metallomics 3, 1109-1118. http:/ dx.doi.org/10.1039/C1MT00107H.

Eapen, S., D'Souza, S.F., 2005. Prospects of genetic engineering of plants for phytoremediation of toxic metals. Biotechnol. Adv. 23, 97-114. http://dx.doi.org/ 10.1016/j.biotechadv.2004.10.001.

Egamberdiyeva, D., 2007. The effect of plant growth promoting bacteria on growth and nutrient uptake of maize in two different soils. Appl. Soil Ecol. 36, 184-189. http://dx.doi.org/10.1016/j.apsoil.2007.02.005.

Eker, S., Ozturk, L., Yazici, A., Erenoglu, B., Romheld, V., Cakmak, I., 2006. Foliarapplied glyphosate substantially reduced uptake and transport of iron and manganese in sunflower (Helianthus annuus L.) plants. J. Agric. Food Chem. 54 10019-10025. http://dx.doi.org/10.1021/jf0625196.

FAOSTAT, 2012. Area of Vineyard, p. 113 [WWW Document]. URL P3.REU.FAO.ESS.GRP.AH.SC.

Fatnassi, I.C., Chiboub, M., Saadani, O., Jebara, M., Jebara, S.H., 2015. Impact of dual inoculation with Rhizobium and PGPR on growth and antioxidant status of Vicia faba L. under copper stress. C. R. Biol. 338, 241-254. http://dx.doi.org/10.1016/ j.crvi.2015.02.001. 
Fernández-Calviño, D., Nóvoa-Muñoz, J.C., Díaz-Raviña, M., Arias-Estévez, M., 2009. Copper accumulation and fractionation in vineyard soils from temperate humid zone (NW Iberian Peninsula). Geoderma 153, 119-129. http://dx.doi.org 10.1016/j.geoderma.2009.07.024.

Fernández-Calviño, D., Soler-Rovira, P., Polo, A., Díaz-Raviña, M., Arias-Estévez, M., Plaza, C., 2010. Enzyme activities in vineyard soils long-term treated with copper-based fungicides. Soil Biol. Biochem. 42, 2119-2127. http://dx.doi.org/ 10.1016/j.soilbio.2010.08.007.

Ferreira, P.A.A., Brunetto, G., Giachini, A.J., Soares, C.R.F.S., 2014. Heavy metal uptake and the effect on plant growth. In: Heavy Metal Remediation: Transport and Accumulation in Plants, pp. 127-154.

Flores-Vélez, L.M., Ducaroir, J., Jaunet, A.M., Robert, M., 1996. Study of the distribution of copper in an acid sandy vineyard soil by three different methods. Eur. J. Soil Sci. 47, 523-532.

Foyer, C.H., Noctor, G., 2011. Ascorbate and glutathione: the heart of the redox hub. Plant Physiol. 155, 2-18. http://dx.doi.org/10.1104/pp.110.167569.

Garrido, F., Illera, V., García-González, M.T., 2005. Effect of the addition of gypsumand lime-rich industrial by-products on $\mathrm{Cd}, \mathrm{Cu}$ and $\mathrm{Pb}$ availability and leachability in metal-spiked acid soils. Appl. Geochem. 20, 397-408. http:// dx.doi.org/10.1016/j.apgeochem.2004.08.001.

Glick, B., Cheng, Z., Czarny, J., Duan, J., 2007. Promotion of plant growth by ACC deaminase-producing soil bacteria. Eur. J. Plant Pathol. 119, 329-339. http:// dx.doi.org/10.1007/s10658-007-9162-4.

Glick, B.R., 2010. Using soil bacteria to facilitate phytoremediation. Biotechnol. Adv. 28, 367-374. http://dx.doi.org/10.1016/j.biotechadv.2010.02.001.

Glick, B.R., 1995. The enhancement of plant growth by free-living bacteria. Can. J. Microbiol. 41, 109-117. http://dx.doi.org/10.1139/m95-015.

Graham, R.D., 1979. Transport of copper and manganese to the xylem exudate of sunflower. Plant. Cell Environ. 2, 139-143. http://dx.doi.org/10.1111/j.13653040.1979.tb00784.x.

Gupta, S.K., Aten, C., 1993. Comparison and evaluation of extraction media and their suitability in a simple model to predict the biological relevance of heavy metal concentrations in contaminated soils. Int. J. Environ. Anal. Chem. 51, 25-46. http://dx.doi.org/10.1080/03067319308027609.

Halliwell, B., Gutteridge, J.M.C., 1990. Role of free radicals and catalytic metal ions in human disease: an overview. Methods Enzymol. 186, 1-85. http://dx.doi.org/ 10.1016/0076-6879(90)86093-B.

Halliwell, B., Gutteridge, J.M.C., 1984. Oxygen toxicity, oxygen radicals, transition metals and disease. Biochem. J. 219, 1-14

Haynes, W. (Ed.), 2010. CRC Handbook of Chemistry and Physics, 91st ed. CRC Press, Taylor and Francis Group, Boca Raton, FL.

He, C.Q., Tan, G.E., Liang, X., Du, W., Chen, Y.L., Zhi, G.Y., Zhu, Y., 2010. Effect of Zntolerant bacterial strains on growth and $\mathrm{Zn}$ accumulation in Orychophragmus violaceus. Appl. Soil Ecol. 44,1-5. http://dx.doi.org/10.1016/j.apsoil.2009.07.003.

He, L.-Y., Chen, Z.-J., Ren, G.-D., Zhang, Y.-F., Qian, M., Sheng, X.-F., 2009. Increased cadmium and lead uptake of a cadmium hyperaccumulator tomato by cadmium-resistant bacteria. Ecotoxicol. Environ. Saf. 72, 1343-1348. http: dx.doi.org/10.1016/j.ecoenv.2009.03.006.

Heim, A., Brunner, I., Frey, B., Frossard, E., Luster, J., 2001. Root exudation, organic acids, and element distribution in roots of Norway spruce seedlings treated with aluminum in hydroponics. J. Plant Nutr. Soil Sci. 164, 519-526. http:/ dx.doi.org/10.1002/1522-2624(200110)164:5<519::AID-JPLN519>3.0.CO;2-Y.

Herrero-Hernández, E., Andrades, M.S., Rodríguez-Cruz, M.S., Sánchez-Martín, M.J., 2011. Effect of spent mushroom substrate applied to vineyard soil on the behaviour of copper-based fungicide residues. J. Environ. Manage 92, 1849-1857. http://dx.doi.org/10.1016/j.jenvman.2011.03.011.

Hinsinger, P., Bengough, A.G., Vetterlein, D., Young, I., 2009. Rhizosphere biophysics, biogeochemistry and ecological relevance. Plant Soil 321, 117-152. http://dx.doi.org/10.1007/s11104-008-9885-9.

Honma, M., Shimomura, T., 1978. Metabolism of 1-aminocyclopropane-1-carboxylic acid. Agric. Biol. Chem. 42, 1825-1831. http://dx.doi.org/10.1080/ 00021369.1978 .10863261$.

Hsu, J.-H., Lo, S.-L., 2000. Characterization and extractability of Copper, Manganese, and Zinc in swine manure composts. J. Environ. Qual. 29, 447-453. http:// dx.doi.org/10.2134/jeq2000.00472425002900020012x.

Huang, G., Guo, G., Yao, S., Zhang, N., Hu, H., 2015. Organic acids, amino acids compositions in the root exudates and $\mathrm{Cu}$-accumulation in castor (Ricinus communis L.) under $\mathrm{Cu}$ stress. Int. J. Phytoremediation. http://dx.doi.org/ $10.1080 / 15226514.2015 .1058333$.

Huffman, D.L., O'Halloran, T.V., 2000. Energetics of copper trafficking between the Atx1 metallochaperone and the intracellular copper transporter, Ccc2. J. Biol. Chem. 275, 18611-18614. http://dx.doi.org/10.1074/jbc.C000172200.

Iacuzzo, F., Gottardi, S., Tomasi, N., Savoia, E., Tommasi, R., Cortella, G., Terzano, R. Pinton, R., Dalla Costa, L., Cesco, S., 2011. Corn salad (Valerianella locusta (L.) Laterr.) growth in a water-saving floating system as affected by iron and sulfate availability. J. Sci. Food Agric. 91, 344-354. http://dx.doi.org/10.1002/jsfa.4192.

Jackson, B.P., Miller, W.P., 2000. Soil solution chemistry of a fly ash-, poultry litterand sewage sludge-amended soil. J. Environ. Qual. 29, 430-436. http:// dx.doi.org/10.2134/jeq2000.00472425002900020009x.

Jones, D., 1998. Organic acids in the rhizosphere - a critical review. Plant Soil 205, 25-44. http://dx.doi.org/10.1023/A:1004356007312.

Jones, D., Darrah, P., 1994. Role of root derived organic acids in the mobilization of nutrients from the rhizosphere. Plant Soil 166, 247-257. http://dx.doi.org/ 10.1007/BF00008338.

Joris, H.A.W., Da Fonseca, A.F., Asami, V.Y., Briedis, C., Borszowskei, P.R., Garbuio, F.J.
2012. Heavy metals adsorption after surface lime in a Rhodic Hapludox under no-tillage system. Rev. Cienc. Agron. 43, 1-10.

Juang, K.-W., Lee, Y.-I., Lai, H.-Y., Chen, B.-C., 2014. Influence of magnesium on copper phytotoxicity to and accumulation and translocation in grapevines. Ecotoxicol. Environ. Saf. 104, 36-42. http://dx.doi.org/10.1016/ j.ecoenv 2014.02.008.

Juang, K.-W., Lee, Y.-I., Lai, H.-Y., Wang, C.-H., Chen, B.-C., 2011. Copper accumulation, translocation, and toxic effects in grapevine cuttings. Environ. Sci. Pollut. Res. 19, 1315-1322. http://dx.doi.org/10.1007/s11356-011-0657-3.

Karlsson, T., Persson, P., Skyllberg, U., 2006. Complexation of Copper(II) in organic soils and in dissolved organic matter - EXAFS evidence for chelate ring structures. Environ. Sci. Technol. 40, 2623-2628. http://dx.doi.org/10.1021/ es052211f.

Khanlari, Z.V., Jalali, M., 2008. Concentrations and chemical speciation of five heavy metals ( $\mathrm{Zn}, \mathrm{Cd}, \mathrm{Ni}, \mathrm{Cu}$, and $\mathrm{Pb}$ ) in selected agricultural calcareous soils of Hamadan Province, western Iran. Arch. Agron. Soil Sci. 54, 19-32. http:// dx.doi.org/10.1080/03650340701697317.

Kochian, L.V., Hoekenga, O.A., Piñeros, M.A., 2004. How do crop plants tolerate acid soils? mechanisms of aluminum tolerance and phosphorus deficiency. Annu. Rev. Plant Biol. 55, 459-493. http://dx.doi.org/10.1146/ annurev.arplant.55.031903.141655.

Kochian, L., 1991. Mechanisms of micronutrient uptake and translocation in plants. In: Mortvedt, J., Cox, F., Shuman, L., Welch, R. (Eds.), Micronutrients in Agriculture. Soil Science Society of America, Madison, pp. 119-296.

Komárek, M., Čadková, E., Chrastný, V., Bordas, F., Bollinger, J.C., 2010. Contamination of vineyard soils with fungicides: a review of environmental and toxicological aspects. Environ. Int. 36, 138-151. http://dx.doi.org/10.1016/ j.envint.2009.10.005.

Korshunova, Y., Eide, D., Gregg Clark, W., Lou Guerinot, M., Pakrasi, H., 1999. The IRT1 protein from Arabidopsis thaliana is a metal transporter with a broad substrate range. Plant Mol. Biol. 40, 37-44. http://dx.doi.org/10.1023/A: 1026438615520

Kotrba, P., Najmanova, J., Macek, T., Ruml, T., Mackova, M., 2009. Genetically modified plants in phytoremediation of heavy metal and metalloid soil and sediment pollution. Biotechnol. Adv. 27, 799-810. http://dx.doi.org/10.1016/ j.biotechadv.2009.06.003.

Krämer, U., Chardonnens, A.N., 2001. The use of transgenic plants in the bioremediation of soils contaminated with trace elements. Appl. Microbiol. Biotechnol. 55, 661-672. http://dx.doi.org/10.1007/s002530100631.

Kremer, R.J., Means, N.E., Kim, S., 2005. Glyphosate affects soybean root exudation and rhizosphere micro-organisms. Int. J. Environ. Anal. Chem. 85, 1165-1174. http://dx.doi.org/10.1080/03067310500273146.

Kumpiene, J., Lagerkvist, A., Maurice, C., 2008. Stabilization of $\mathrm{As}, \mathrm{Cr}, \mathrm{Cu}, \mathrm{Pb}$ and $\mathrm{Zn}$ in soil using amendments - a review. Waste Manag. 28, 215-225. http:/ dx.doi.org/10.1016/j.wasman.2006.12.012.

Kuwajima, K., Kawai, S., 1997. Relationship between sulfur metabolism and biosynthesis of phytosiderophores in barley roots. In: Ando, T., Fujita, K., Mae, T. Matsumoto, H., Mori, S., Sekiya, J. (Eds.), Plant Nutrition for Sustainable Food Production and Environment. Kluwer Academic Publishers, Dordrecht.

Liao, M.T., Hedley, M.J., Woolley, D.J., Brooks, R.R., Nichols, M.A., 2000a. Copper uptake and translocation in chicory (Cichorium intybus L. cv Grasslands Puna) and tomato (Lycopersicon esculentum Mill. cv Rondy) plants grown in NFT system. II. The role of nicotianamine and histidine in xylem sap copper transport. Plant Soil 223, 245-254. http://dx.doi.org/10.1023/A:1004843505053.

Liao, M.T., Hedley, M.J., Woolley, D.J., Brooks, R.R., Nichols, M.A., 2000b. Copper uptake and translocation in chicory ( Cichorium intybus L. cv. Grasslands Puna) and tomato (Lycopersicon esculentum Mill. cv. Rondy) plants grown in NFT system. I. Copper uptake and distribution in plants. Plant Soil 221, 135-142. http://dx.doi.org/10.1023/A:1004731415931.

Liu, T., Sun, C., Ta, N., Hong, J., Yang, S., Chen, C., 2007. Effect of copper on the degradation of pesticides cypermethrin and cyhalothrin. J. Environ. Sci. 19, 1235-1238, http:/dx doi oro/101016/S1001-0742(07)60201-0.

Lorestani, B., Yousefi, N., Cheraghi, M., Farmany, A., 2013. Phytoextraction and phytostabilization potential of plants grown in the vicinity of heavy metalcontaminated soils: a case study at an industrial town site. Environ. Monit. Assess. 185, 10217-10223. http://dx.doi.org/10.1007/s10661-013-3326-9.

Lux, A., Martinka, M., Vaculík, M., White, P.J., 2011. Root responses to cadmium in the rhizosphere: a review. J. Exp. Bot. 62, 21-37. http://dx.doi.org/10.1093/jxb/ erq281.

Mackie, K.A., Müller, T., Zikeli, S., Kandeler, E., 2013. Long-term copper application in an organic vineyard modifies spatial distribution of soil micro-organisms. Soil Biol. Biochem, 65, 245-253. http://dx doi.org/10.1016/j.soilbio.2013.06.003.

Macomber, L., Imlay, J.A., 2009. The iron-sulfur clusters of dehydratases are primary intracellular targets of copper toxicity. Proc. Natl. Acad. Sci. 106, 8344-8349. http://dx.doi.org/10.1073/pnas.0812808106.

Magdziak, Z., Kozlowska, M., Kaczmarek, Z., Mleczek, M., Chadzinikolau, T., Drzewiecka, K., Golinski, P., 2011. Influence of $\mathrm{Ca} / \mathrm{Mg}$ ratio on phytoextraction properties of Salix viminalis. II. Secretion of low molecular weight organic acids to the rhizosphere. Ecotoxicol. Environ. Saf. 74, 33-40. http://dx.doi.org/ 10.1016/j.ecoenv.2010.09.003.

Manceau, A., Matynia, A., 2010. The nature of $\mathrm{Cu}$ bonding to natural organic matter. Geochim. Cosmochim. Acta 74, 2556-2580. http://dx.doi.org/10.1016/ j.gca.2010.01.027.

Manderscheid, R., Schaaf, S., Mattsson, M., Schjoerring, J.K., 2005. Glufosinate treatment of weeds results in ammonia emission by plants. Agric. Ecosyst. 
Environ. 109, 129-140. http://dx.doi.org/10.1016/j.agee.2005.01.016.

Marschner, P., 2011. Marschner's Mineral Nutrition of Higher Plants, third ed. London.

Martell, A.E., Smith, R.M., Matekaitis, R.J., 2004. Database 46: NIST Critically Selected Constants of Metal Complexes.

McBride, M., 1994. Trace and toxic elements in soils. In: McBride, M. (Ed.), Environmental Chemistry of Soils. Oxford Univ. Press, New York, pp. 308-341.

McBride, M., 1979. Mobility and reactions of VO2+ on hydrated smectite surfaces. Clays Clay Min. 27, 91-96.

McGrath, S.P., Zhao, F.J., 1995. A risk assessment of sulphur deficiency in cereals using soil and atmospheric deposition data. Soil Use Manag. 11, 110-114. http:// dx.doi.org/10.1111/j.1475-2743.1995.tb00507.x.

McGrath, S.P., Zhao, J., Lombi, E., 2002. Phytoremediation of metals, metalloids, and radionuclides. In: Agronomy. Academic Press, pp. 1-56. http://dx.doi.org/ 10.1016/S0065-2113(02)75002-5.

Meier, S., Alvear, M., Borie, F., Aguilera, P., Ginocchio, R., Cornejo, P., 2012. Influence of copper on root exudate patterns in some metallophytes and agricultural plants. Ecotoxicol. Environ. Saf. 75, 8-15. http://dx.doi.org/10.1016/ j.ecoenv.2011.08.029.

Mimmo, T., Del Buono, D., Terzano, R., Tomasi, N., Vigani, G., Crecchio, C., Pinton, R., Zocchi, G., Cesco, S., 2014. Rhizospheric organic compounds in the soilmicroorganism-plant system: their role in iron availability. Eur. J. Soil Sci. 65 , 629-642. http://dx.doi.org/10.1111/ejss.12158.

Mimmo, T., Hann, S., Jaitz, L., Cesco, S., Gessa, C.E., Puschenreiter, M., 2011. Time and substrate dependent exudation of carboxylates by Lupinus albus L. and Brassica napus L. Plant Physiol. Biochem. 49, 1272-1278. http://dx.doi.org/10.1016/ j.plaphy.2011.08.012.

Miotto, A., Ceretta, C.A., Brunetto, G., Nicoloso, F.T., Girotto, E., Farias, J.G., Tiecher, T.L., Conti, L., Trentin, G., 2013. Copper uptake, accumulation and physiological changes in adult grapevines in response to excess copper in soil. Plant Soil 374, 593-610. http://dx.doi.org/10.1007/s11104-013-1886-7.

Mirlean, N., Roisenberg, A., Chies, J.O., 2007. Metal contamination of vineyard soils in wet subtropics (southern Brazil). Environ. Pollut. 149, 10-17. http:/ dx.doi.org/10.1016/j.envpol.2006.12.024.

Mukherjee, S., Das, P., Sen, R., 2006. Towards commercial production of microbial surfactants. Trends Biotechnol. 24, 509-515. http://dx.doi.org/10.1016/ j.tibtech.2006.09.005.

Nie, L., Shah, S., Rashid, A., Burd, G.I., George Dixon, D., Glick, B.R., 2002. Phytoremediation of arsenate contaminated soil by transgenic canola and the plant growth-promoting bacterium Enterobacter cloacae CAL2. Plant Physiol. Biochem. 40, 355-361. http://dx.doi.org/10.1016/S0981-9428(02)01375-X.

Nikolic, M., Cesco, S., Römheld, V., Varanini, Z., Pinton, R., 2007. Short-term interactions between nitrate and iron nutrition in cucumber. Funct. Plant Biol.

Oburger, E., Gruber, B., Schindlegger, Y., Schenkeveld, W.D.C., Hann, S. Kraemer, S.M., Wenzel, W.W., Puschenreiter, M., 2014. Root exudation of phytosiderophores from soil-grown wheat. New Phytol. 203, 1161-1174. http:// dx.doi.org/10.1111/nph.12868.

Oburger, E., Kirk, G.J.D., Wenzel, W.W., Puschenreiter, M., Jones, D.L., 2009. Interactive effects of organic acids in the rhizosphere. Soil Biol. Biochem. 41, 449-457. http://dx.doi.org/10.1016/j.soilbio.2008.10.034.

Ojeda-Real, L.A., Lobit, P., Cárdenas-Navarro, R., Grageda-Cabrera, O., FaríasRodríguez, R., Valencia-Cantero, E., Macías-Rodríguez, L., 2009. Effect of nitrogen fertilization on quality markers of strawberry (Fragaria $\times$ ananassa Duch. cv. Aromas). J. Sci. Food Agric. 89, 935-939. http://dx.doi.org/10.1002/jsfa.3531.

Ough, C.S., Bell, A.A., 1980. Effects of nitrogen fertilization of grapevines on amino acid metabolism and higher-alcohol formation during grape juice fermentation. Am. J. Enol. Vitic. 31, 122-123.

Ouzounidou, G., 1995. Effect of copper on germination and seedling growth of minuartia, Silene, Alyssum and Thlaspi. Biol. Plant 37, 411-416. http:// dx.doi.org/10.1007/BF02913990.

Papoyan, A., Kochian, L.V., 2004. Identification of Thlaspi caerulescens genes that may be involved in heavy metal hyperaccumulation and tolerance. Characterization of a novel heavy metal transporting ATPase. Plant Physiol. 136, 3814-3823.

Parisi, M., Giordano, L., Pentangelo, A., D'Onofrio, B., Villari, G., 2006. Effects of different levels of nitrogen fertilization on yield and fruit quality in processing tomato. In: Acta Horticulturae. International Society for Horticultural Science (ISHS), Leuven, Belgium, pp. 129-132. http://dx.doi.org/10.17660/ ActaHortic. 2006.700.19.

Pérez-Esteban, J., Escolástico, C., Masaguer, A., Vargas, C., Moliner, A., 2014. Soluble organic carbon and $\mathrm{pH}$ of organic amendments affect metal mobility and chemical speciation in mine soils. Chemosphere 103, 164-171. http:// dx.doi.org/10.1016/j.chemosphere.2013.11.055.

Pich, A., Scholz, G., 1996. Translocation of copper and other micronutrients in tomato plants (Lycopersicon esculentum Mill.): nicotianamine-stimulated copper transport in the xylem. J. Exp. Bot. 47, 41-47. http://dx.doi.org/10.1093/jxb/ 47.1.41.

Pietrzak, U., McPhail, D.C., 2004. Copper accumulation, distribution and fractionation in vineyard soils of Victoria, Australia. Geoderma 122, 151-166. http:// dx.doi.org/10.1016/j.geoderma.2004.01.005.

Pietrzak, U., Uren, N.C., 2011. Remedial options for copper-contaminated vineyard soils. Soil Res. 49, 44-55.

Pii, Y., Borruso, L., Brusetti, L., Crecchio, C., Cesco, S., Mimmo, T., 2016. The interaction between iron nutrition, plant species and soil type shapes the rhizosphere microbiome. Plant Physiol. Biochem. 99, 39-48. http://dx.doi.org/ 10.1016/j.plaphy.2015.12.002.

Pii, Y., Mimmo, T., Tomasi, N., Terzano, R., Cesco, S., Crecchio, C., 2015. Microbial interactions in the rhizosphere: beneficial influences of plant growthpromoting rhizobacteria on nutrient acquisition process. A review. Biol. Fertil. Soils 51, 403-415. http://dx.doi.org/10.1007/s00374-015-0996-1.

Prosser, I.M., Purves, J.V., Saker, L.R., Clarkson, D.T., 2001. Rapid disruption of nitrogen metabolism and nitrate transport in spinach plants deprived of sulphate. J. Exp. Bot. 52, 113-121. http://dx.doi.org/10.1093/jexbot/52.354.113.

Puig, S., Thiele, D.J., 2002. Molecular mechanisms of copper uptake and distribution. Curr. Opin. Chem. Biol. 6, 171-180. http://dx.doi.org/10.1016/S1367-5931(02) 00298-3.

Qin, R., Hirano, Y., Brunner, I., 2007. Exudation of organic acid anions from poplar roots after exposure to $\mathrm{Al}, \mathrm{Cu}$ and $\mathrm{Zn}$. Tree Physiol. 27, 313-320. http:/ dx.doi.org/10.1093/treephys/27.2.313.

Rajkumar, M., Freitas, H., 2008. Influence of metal resistant-plant growth-promoting bacteria on the growth of Ricinus communis in soil contaminated with heavy metals. Chemosphere 71, 834-842. http://dx.doi.org/10.1016/ j.chemosphere.2007.11.038.

Reed, M.L.E., Glick, B.R., 2005. Growth of canola (Brassica napus) in the presence of plant growth-promoting bacteria and either copper or polycyclic aromatic hydrocarbons. Can. J. Microbiol. 51, 1061-1069. http://dx.doi.org/10.1139/w05094.

Reed, M.L.E., Warner, B., Glick, B., 2005. Plant Growth-Promoting Bacteria facilitate the growth of the common reed Phragmites australisin the presence of copper or polycyclic aromatic hydrocarbons. Curr. Microbiol. 51, 425-429. http:// dx.doi.org/10.1007/s00284-005-4584-8.

Rengel, Z., Wheal, M.S., 1997. Herbicide chlorsulfuron decreases growth of fine roots and micronutrient uptake in wheat genotypes. J. Exp. Bot. 48, 927-934. http:// dx.doi.org/10.1093/jxb/48.4.927.

Robson, A.D., Snowball, K., 1990. The effect of chlorsulfuron on the uptake and utilization of copper and zinc in wheat. Aust. J. Agric. Res. 41, 19-27.

Ruttens, A., Mench, M., Colpaert, J.V., Boisson, J., Carleer, R., Vangronsveld, J., 2006 Phytostabilization of a metal contaminated sandy soil. I: influence of compost and/or inorganic metal immobilizing soil amendments on phytotoxicity and plant availability of metals. Environ. Pollut. 144, 524-532. http://dx.doi.org/ 10.1016/j.envpol.2006.01.038.

Ruyters, S., Salaets, P., Oorts, K., Smolders, E., 2013. Copper toxicity in soils under established vineyards in Europe: a survey. Sci. Total Environ. 443, 470-477. http://dx.doi.org/10.1016/j.scitotenv.2012.11.001.

Safronova, V., Stepanok, V., Engqvist, G., Alekseyev, Y., Belimov, A., 2006. Rootassociated bacteria containing 1-aminocyclopropane-1-carboxylate deaminase improve growth and nutrient uptake by pea genotypes cultivated in cadmium supplemented soil. Biol. Fertil. Soils 42, 267-272. http://dx.doi.org/10.1007 s00374-005-0024-y.

Sancenón, V., Puig, S., Mira, H., Thiele, D.J., Peñarrubia, L., 2003. Identification of a copper transporter family in Arabidopsis thaliana. Plant Mol. Biol. 51, 577-587. http://dx.doi.org/10.1023/A:1022345507112.

Shahbaz, M. Tseng, M., Stuiver, C., Posthumus, F., Parmar, S., Koralewska, A. Hawkesford, M., De Kok, L., 2010. Impact of copper exposure on physiologica functioning of Chinese cabbage (Brassica pekinensis). In: Sequi, P., Ferri, D. Rea, E., Montemurro, A., Fornado, F. (Eds.), More Sustainability in Agriculture: New Fertilizers and Fertilizer Management, pp. 318-324.

Shaheen, S.M., Tsadilas, C.D., Rinklebe, J., 2015. Immobilization of soil copper using organic and inorganic amendments. J. Plant Nutr. Soil Sci. 178, 112-117. http:/ dx.doi.org/10.1002/jpln.201400400.

Shimabukuro, R.H., Hoffer, B.L., 1994. Effects on transmembrane proton gradient and lipid biosynthesis in the mode of action of diclofop-methyl. Pestic. Biochem. Physiol. 48, 85-97. http://dx.doi.org/10.1006/pest.1994.1010.

Solioz, M., Vulpe, C., 1996. CPx-type ATPases: a class of P-type ATPases that pump heavy metals. Trends Biochem. Sci. 21, 237-241. http://dx.doi.org/10.1016| S0968-0004(96)20016-7.

Sparks, D., 2003. Environmental Soil Chemistry. Academic Press.

Sposito, G., 1989. The Chemistry of Soils. New York.

Stadtman, E.R., 1992. Protein oxidation and aging. Sci. (80-. ) 257, 1220-1224.

Strawn, D.G., Baker, L.L., 2009. Molecular characterization of copper in soils using Xray absorption spectroscopy. Environ. Pollut. 157, 2813-2821. http://dx.doi.org/ 10.1016/j.envpol.2009.04.018.

Su, D.C., Wong, J.W.C., 2004. Chemical speciation and phytoavailability of $\mathrm{Zn}, \mathrm{Cu}, \mathrm{Ni}$ and $\mathrm{Cd}$ in soil amended with fly ash-stabilized sewage sludge. Environ. Int. 29 , 895-900. http://dx.doi.org/10.1016/S0160-4120(03)00052-7.

Sun, L., Zheng, C., Yang, J., Peng, C., Xu, C., Wang, Y., Feng, J., Shi, J., 2016. Impact of sulfur $(\mathrm{S})$ fertilization in paddy soils on copper $(\mathrm{Cu})$ accumulation in rice (Oryza sativa L.) plants under flooding conditions. Biol. Fertil. Soils 52, 31-39. http:/ dx.doi.org/10.1007/s00374-015-1050-z.

Tang, C., Robson, A.D., 2000. Cultivar variation in the effect of chlorsulfuron in depressing the uptake of copper in wheat. Plant Soil 225, 11-20. http:/ dx.doi.org/10.1023/A:1026598918181.

Tanyolaç, D., Ekmekçi, Y., Ünalan, Ş., 2007. Changes in photochemical and antioxidant enzyme activities in maize (Zea mays L.) leaves exposed to excess copper. Chemosphere 67, 89-98. http://dx.doi.org/10.1016/j.chemosphere.2006.09.052.

Terzano, R., Cesco, S., Mimmo, T., 2014. Dynamics, thermodynamics and kinetics of exudates: crucial issues in understanding rhizosphere processes. Plant Soil 386 399-406. http://dx.doi.org/10.1007/s11104-014-2308-1.

Terzano, R., Spagnuolo, M., Medici, L., Tateo, F., Ruggiero, P., 2005a. Zeolite synthesis from pre-treated coal fly ash in presence of soil as a tool for soil remediation. 
Appl. Clay Sci. 29, 99-110. http://dx.doi.org/10.1016/j.clay.2004.12.006.

Terzano, R. Spagnuolo, M., Medici, L., Vekemans, B., Vincze, L., Janssens, K. Ruggiero, P., 2005b. Copper stabilization by zeolite synthesis in polluted soils treated with coal fly ash. Environ. Sci. Technol. 39, 6280-6287. http:// dx.doi.org/10.1021/es050079d.

Toselli, M., Schiatti, P., Ara, D., Bertacchini, A., Quartieri, M., 2009. The accumulation of copper in soils of the Italian region Emilia-Romagna. Plant Soil Environ. 55, 74-79.

Tóth, G., Hermann, T., Da Silva, M.R., Montanarella, L., 2016. Heavy metals in agricultural soils of the European Union with implications for food safety. Environ. Int. 88, 299-309. http://dx.doi.org/10.1016/j.envint.2015.12.017.

Uchimiya, M., Klasson, K.T., Wartelle, L.H., Lima, I.M., 2011. Influence of soil properties on heavy metal sequestration by biochar amendment: 1 . Copper sorption isotherms and the release of cations. Chemosphere 82, 1431-1437. http:// dx.doi.org/10.1016/j.chemosphere.2010.11.050.

Valentinuzzi, F., Mimmo, T., Cesco, S., Al Mamun, S., Santner, J., Hoefer, C., Oburger, E., Robinson, B., Lehto, N., 2015. The effect of lime on the rhizosphere processes and elemental uptake of white lupin. Environ. Exp. Bot. 118, 85-94. http://dx.doi.org/10.1016/j.envexpbot.2015.06.010.

van der Sloot, H. Heasman, L., Quevauviller, P., 1997. Harmonisation of leaching extraction tests. In: Studies in Environmental Science. Elsevier, Amsterdam.

Van Hoof, N.A.L.M., Koevoets, P.L.M., Hakvoort, H.W.J., Ten Bookum, W.M., Schat, H. Verkleij, J.A.C., Ernst, W.H.O., 2001. Enhanced ATP-dependent copper efflux across the root cell plasma membrane in copper-tolerant Silene vulgaris. Physiol. Plant 113, 225-232. http://dx.doi.org/10.1034/j.13993054.2001.1130210.x.

Vivas, A., Biró, B., Németh, T., Barea, J.M., Azcón, R., 2006. Nickel-tolerant Brevibacillus brevis and arbuscular mycorrhizal fungus can reduce metal acquisition and nickel toxicity effects in plant growing in nickel supplemented soil. Soil Biol. Biochem. 38, 2694-2704. http://dx.doi.org/10.1016/j.soilbio.2006.04.020.

Von Wiren, N., Marschner, H., Romheld, V., 1996. Roots of Iron-efficient maize also absorb phytosiderophore-chelated Zinc. Plant Physiol. 111, 1119-1125.

Weisskopf, L., Abou-Mansour, E., Fromin, N., Tomasi, N., Santelia, D., Edelkott, I. Neumann, G., Aragno, M., Tabacchi, R., Martinoia, E., 2006. White lupin has developed a complex strategy to limit microbial degradation of secreted citrate required for phosphate acquisition. Plant Cell Environ. 29, 919-927. http:// dx.doi.org/10.1111/j.1365-3040.2005.01473.x.

Welch, R.M., Shuman, L., 1995. Micronutrient nutrition of plants. CRC. Crit. Rev. Plant Sci. 14, 49-82. http://dx.doi.org/10.1080/07352689509701922.

Wenzel, W.W., Bunkowski, M., Puschenreiter, M., Horak, O., 2003. Rhizosphere characteristics of indigenously growing nickel hyperaccumulator and excluder plants on serpentine soil. Environ. Pollut. 123, 131-138. http://dx.doi.org/ 10.1016/S0269-7491(02)00341-X.

White, M.C., Decker, A.M., Chaney, R.L., 1981. Metal Complexation in Xylem Fluid: I.
Chemical composition of tomato and soybean stem exudate. Plant Physiol. 67, 292-300. http://dx.doi.org/10.1104/pp.67.2.292.

Wintz, H., Fox, T., Wu, Y.-Y., Feng, V., Chen, W., Chang, H.-S., Zhu, T., Vulpe, C., 2003. Expression profiles of Arabidopsis thaliana in mineral deficiencies reveal novel transporters involved in metal homeostasis. J. Biol. Chem. 278, 47644-47653. http://dx.doi.org/10.1074/jbc.M309338200.

Wright, J.P., 1994. Use of membrane potential measurements to study mode of action of diclofop-methyl. Weed Sci. 42, 285-292.

Xiaorong, W., Mingde, H., Mingan, S., 2007. Copper fertilizer effects on copper distribution and vertical transport in soils. Geoderma 138, 213-220. http:// dx.doi.org/10.1016/j.geoderma.2006.11.012.

Xiong, H., Kakei, Y., Kobayashi, T., Guo, X., Nakazono, M., Takahashi, H., Nakanishi, H., Shen, H., Zhang, F., Nishizawa, N.K., Zuo, Y., 2013. Molecular evidence for phytosiderophore-induced improvement of iron nutrition of peanut intercropped with maize in calcareous soil. Plant. Cell Environ. 36, 1888-1902. http://dx.doi.org/10.1111/pce.12097.

Yau, P.Y., Loh, C.F., Azmil, I.A.R., 1991. Copper toxicity of clove [Syzygium aromaticum (L.) Merr. and Perry] seedlings. MARDI Res. J. 19, 49-53.

Yruela, I., 2009. Copper in plants: acquisition, transport and interactions. Funct Plant Biol. 36, 409-430.

Yruela, I., 2005. Copper in plants. Braz. J. Plant Physiol. 17, 145-156.

Zhang, F., Römheld, V., Marschner, H., 1989. Effect of zinc deficiency in wheat on the release of zinc and iron mobilizing root exudates. Z. für Pflanzenernährung Bodenkd 152, 205-210. http://dx.doi.org/10.1002/jpln.19891520211.

Zhang, L., Pan, Y., Lv, W., Xiong, Z., 2014. Physiological responses of biomass allocation, root architecture, and invertase activity to copper stress in young seedlings from two populations of Kummerowia stipulacea (maxim.) Makino. Ecotoxicol. Environ. Saf. 104, 278-284. http://dx.doi.org/10.1016/ j.ecoenv.2014.03.013.

Zhu, Y.L., Pilon-Smits, E.A.H., Jouanin, L., Terry, N., 1999. Overexpression of glutathione synthetase in Indian mustard enhances cadmium accumulation and tolerance. Plant Physiol. 119, 73-79.

Zimmermann, M., Clarke, O., Gulbis, J.M., Keizer, D.W., Jarvis, R.S., Cobbett, C.S. Hinds, M.G. Xiao, Z. Wedd, A.G., 2009. Metal binding affinities of Arabidopsis Zinc and Copper transporters: selectivities match the relative, but not the absolute, affinities of their amino-terminal domains. Biochemistry 48, 11640-11654. http://dx.doi.org/10.1021/bi901573b.

Zuchi, S., Cesco, S., Astolfi, S., 2012. High S supply improves Fe accumulation in durum wheat plants grown under Fe limitation. Environ. Exp. Bot. 77, 25-32. http://dx.doi.org/10.1016/j.envexpbot.2011.11.001.

Zuchi, S., Cesco, S., Varanini, Z., Pinton, R., Astolfi, S., 2009. Sulphur deprivation limits Fe-deficiency responses in tomato plants. Planta 230, 85-94. http:// dx.doi.org/10.1007/s00425-009-0919-1. 